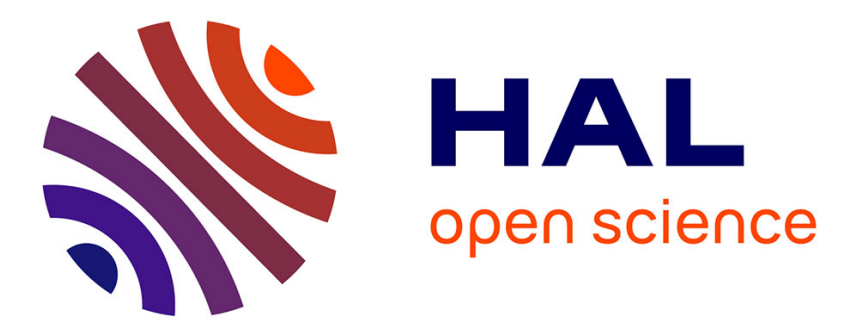

\title{
Modelling and characterizing glacier-bed overdeepenings as sites for potential future lakes in the deglaciating French Alps
}

\author{
Maeva Cathala, Florence Magnin, Andreas Linsbauer, Wilfried Haeberli
}

\section{- To cite this version:}

Maeva Cathala, Florence Magnin, Andreas Linsbauer, Wilfried Haeberli. Modelling and characterizing glacier-bed overdeepenings as sites for potential future lakes in the deglaciating French Alps. Géomorphologie: relief, processus, environnement, 2021, 27, pp.19-36. 10.4000/geomorphologie.15255 . hal-03260843

\section{HAL Id: hal-03260843 \\ https://hal.science/hal-03260843}

Submitted on 15 Jun 2021

HAL is a multi-disciplinary open access archive for the deposit and dissemination of scientific research documents, whether they are published or not. The documents may come from teaching and research institutions in France or abroad, or from public or private research centers.
L'archive ouverte pluridisciplinaire HAL, est destinée au dépôt et à la diffusion de documents scientifiques de niveau recherche, publiés ou non, émanant des établissements d'enseignement et de recherche français ou étrangers, des laboratoires publics ou privés. 


\section{Modelling and characterizing glacier-bed overdeepenings as sites for potential future lakes in the deglaciating French Alps}

Modélisation et caractérisation des surcreusements glaciaires des Alpes françaises pour déterminer les sites des futurs lacs potentiels dans le contexte de désenglacement

Maeva Cathala, Florence Magnin, Andreas Linsbauer et Wilfried Haeberli

\section{(2) OpenEdition}

Édition électronique

URL : https://journals.openedition.org/geomorphologie/15255

ISSN : 1957-777X

\section{Éditeur}

Groupe français de géomorphologie

Édition imprimée

Date de publication : 30 avril 2021

Pagination : 19-36

ISBN : 978-2-913282-90-2

ISSN : $1266-5304$

Ce document vous est offert par Université Savoie Mont Blanc 


\title{
Modelling and characterizing glacier-bed overdeepenings as sites for potential future lakes in the deglaciating French Alps
}

\section{Modélisation et caractérisation des surcreusements glaciaires des Alpes françaises pour dé- terminer les sites des futurs lacs potentiels dans le contexte de désenglacement}

\author{
Maeva Cathala ${ }^{a^{*}}$, Florence Magnin ${ }^{\mathrm{a}}$, Andreas Linsbauer ${ }^{\mathrm{b}, \mathrm{c}}$, Wilfried Haeberli ${ }^{\mathrm{c}}$ \\ ${ }^{a}$ Université Savoie Mont Blanc, Laboratoire EDYTEM UMR 5204 CNRS, Bâtiment « Pôle Montagne », 5 bd de la mer Caspienne, F-73376 Le Bourget du Lac cedex, France \\ ${ }^{\mathrm{b}}$ Department of Geosciences - University of Fribourg - 1700 Fribourg - Switzerland \\ University of Zurich, Department of Geography, Winterthurerstrasse 190, 8057 Zurich, Suisse
}

\section{ARTICLE INFORMATION}

Manuscript received on June 04,2020 revised version received on December 02, 2020 definitively accepted on December 29, 2020

*Auteur correspondant. Tél : +332(0)479758742 E-mail addresses: maeva.cathala@univ-smb.fr (M. Cathala)

florence-magnin@univ-smb.fr (F. Magnin)

andreas.linsbauer@geo.uzh.ch (A. Linsbauer)

wilfried.haeberli@geo.uzh.ch (W. Haeberli)

\begin{abstract}
Glacier retreat results in major landscape changes including the formation of new lakes in Glacier-Bed Overdeepenings (GBOs) that can provoke catastrophic Glacial Lake Outburst Flood (GLOF) hazards, but could also provide economic opportunities. This study aims to identify and characterize the location of potential GBOs in the French Alps as possible sites for future lakes. We first ran GlabTop (Glacier-bed Topography) and GlabTop2 models, two GIS schemes calculating glacier ice thickness and mapping potential GBOs. Their level of confidence is estimated using morphological analysis based on slope angle, crevasse fields and lateral narrowing at bedrock thresholds. 139 GBOs $\left(>0.01 \mathrm{~km}^{2}\right)$ were predicted among which 59 have medium to very high confidence. 20 lakes are already forming at the snout of retreating glaciers, including four lakes at predicted $\mathrm{GBOs}<0,01 \mathrm{~km}^{2}$. The Vanoise massif hosts $43 \%$ of the predicted GBOs but the Mont Blanc massif gathers larger, deeper and more voluminous ones. Most of the predicted GBOs are below 3,500m a.s.l. as related to the elevation of the corresponding glaciers. In the Vanoise massif, many predicted GBOs have rather low confidence because of the extent of ice-cap like glaciers for which the shear stress approach used by GlabTop becomes questionable. Furthermore, 58 potential GBOs were detected by visual analysis of glacier morphologies. The study highlights the relevance of combining various methods to determine GBOs and is a first step towards the anticipation of future risks and opportunities related to the formation of new lakes in the French Alps.
\end{abstract}

Keywords: deglaciating landscapes, Glacier Bed Overdeepenings, potential future lakes, French Alps, hazards anticipation.

\section{RÉSUMÉ}

Dans le contexte actuel de retrait glaciaire, de nouveaux lacs se forment parfois dans les surcreusements des lits glaciaires. Ces lacs peuvent provoquer ou amplifier des aléas naturels (e.g., vidange brutale d'un lac) ou être source d'opportunités économiques. Cette étude vise à identifier et caractériser les surcreusements glaciaires pour déterminer les futurs lacs potentiels dans les Alpes françaises. La topographie sous glaciaire est modélisée grâce aux modèles GlabTop (Glacier-bed Topography) et GlabTop2 qui calculent lépaisseur des glaciers et cartographient les surcreusements potentiels. Le niveau de confiance des surcreusements est estimé en analysant la morphologie des glaciers actuels à leur emplacement (i.e. angle de pente, crevasses, présence/absence de verrou rocheux). 139 surcreusements glaciaires $\left(>0,01 \mathrm{~km}^{2}\right)$ ont été détectés, dont 59 qui ont un niveau de confiance moyen à très élevé. L’approche utilisée est limitée pour les calottes glaciaires, ce qui explique certains faibles niveaux de confiance en Vanoise. 20 lacs se forment déjà au front de certains glaciers, dont quatre dans des surcreusements dont la superficie estimée est $<0,01 \mathrm{~km}^{2} .43 \%$ des surcreusements détectés sont en Vanoise, mais le massif du Mont Blanc rassemble les plus grands, les plus profonds et les plus volumineux. La majorité des surcreusements sont sous 3500 m d’altitude. 58 autres surcreusements potentiels ont également été détectés en analysant visuellement la morphologie des glaciers. L'étude souligne la pertinence de combiner différentes méthodes pour détecter les surcreusements et constitue une étape clé vers l'anticipation des risques et opportunités liés à la formation de nouveaux lacs dans les Alpes françaises.

Mots-clés : désenglacement des paysages, surcreusements glaciaires, futurs lacs potentiels, Alpes françaises, anticipation des aléas naturels.

\section{Introduction}

Global warming is particularly pronounced in high mountain environments and has accelerated in the past decades (Hock et al., 2019). In the French Alps, air temperature has increased by $+1.5^{\circ} \mathrm{C}$ to $+2.1^{\circ} \mathrm{C}$ since 1950 (Einhorn et al., 2015). This has strong impacts on the Alpine cryosphere, such as rising of the rain-snow limit by about $400 \mathrm{~m}$ since the 1980s (Böhm et al., 2010), permafrost degradation (Magnin et al., 2017; PERMOS, 2019) and glacier retreat (Zemp et al., 2015). In the European Alps, glacier surface area has decreased 
by $50 \%$ and glacier volume by some $200 \mathrm{~km}^{3}$ between the end of the Little Ice Age (LIA, 1850) and 2000 (Zemp et al., 2006). This trend has clearly accelerated in the recent decades (Huss, 2012; Zekollari et al., 2019).

The ongoing deglaciation results in an extension of periglacial environments and sometimes of new lakes forming in glacier bed overdeepenings (GBO). These lakes are by essence located in unstable and transient environments. They could be a source of natural hazards related to Glacial Lake Outburst Floods (GLOF) that could be provoked by sudden dam break or by displacement waves triggered by mass movements (Allen et al., 2016b; Ashraf et al., 2012; Clague and Evans, 2000; Emmer, 2017; Hubbard et al., 2005). Glacial lakes are sometimes located near potentially unstable slopes subject to debuttressing and/or permafrost degradation which both can amplify gravitational hazards such as rock avalanches (Haeberli et al., 2017) provoking chains of processes that can travel over long distances and reach valley floors (Byers et al., 2018; Walter et al., 2020). When such far-reaching cascading processes happen in densely populated valleys, the socio-economic impacts can be dramatic (Carey, 2005; Carey et al., 2012). Beyond the threat, those new water bodies can also be an opportunity for hydroelectricity production with the creation of hydraulic dams (Haeberli et al., 2016), or through their attractiveness for tourists (Purdie, 2013). Nevertheless, GBOs not always turn into perennial lakes as they are sometimes filled with sediments, or they can drain when lakes form in permeable morainic material (Haeberli et al., 2001). In the French Alps, this was for example the case at the front of the emblematic Mer de Glace (Mont Blanc massif) where a lake was present in the 1990s but was progressively filled with sediments (Deline et al. 2012; Magnin et al., 2020) or at the snout of Pélerins glacier where a lake formed in 2015 but drained in 2016 (Magnin et al., 2020).

Recently developed models, based on variable physical simplifications and input data are able to calculate spatially distributed ice thicknesses (Farinotti et al., 2009) and the resulting sub-glacial topography, revealing the location of potential GBOs in which lakes could form (Linsbauer et al., 2009, 2012; Paul and Linsbauer, 2012). Such studies have already been conducted in various mountain ranges such as, for instance, the Himalayas (Linsbauer et al., 2016), the Peruvian Andes (Colonia et al. 2017; Drenkhan et al., 2018), Central Asia (Kapitsa et al., 2017) and in Switzerland (Linsbauer et al., 2012). They are a necessary first step towards assessing GLOFs hazards and their impacts (GAPHAZ, 2017) and integrative modelling of future landscapes in glacial and periglacial areas (Haeberli, 2017). In the French Alps, potential future lakes have so far been investigated in the Mont Blanc massif (Magnin et al., 2020).

This work aims at extending the latter study to the entire French Alps in order to provide relevant baseline to anticipate risks and opportunities associated with future lake formation in presently still glacier-covered areas. To do so, we ran GlabTop (Glacier-bed Topography) and GlabTop2 models, two GIS schemes calculating ice thicknesses from surface slope via basal shear stresses, with a different level of automation, and which both provide a map and morphometrics of potential GBOs. This method is combined with a visual analysis based on morphological criteria proposed by Frey et al. (2010), which helps in determining the level of confidence for each modelled GBO. In addition, the results of the simulations are evaluated by comparing predicted GBOs with lakes that newly formed or did not form in recently deglaciated areas. The results finally point to potential "hot spots" that could - or should - be more closely investigated in the future in order to assess related hazards, risks and opportunities.

\section{The French Alps, a deglaciating mountain range}

The French Alps are the western edge of the European Alpine arc and extend from the Mont Blanc massif in the north to the Mercantour adjoining the Mediterranean Sea in the south. With the Pyrenees, it is one of the two, but also the most glacierized mountain range in the mainland of France. According to the inventory by Gardent et al. (2014), 581 glaciers were counted in $2006 / 2009$, covering $275.4 \mathrm{~km}^{2}$. The smallest is a glacieret in the Écrins massif (Bans glacier $-0.0015 \mathrm{~km}^{2}$ ) and the largest is the Mer de Glace in the Mont Blanc massif $\left(30.5 \mathrm{~km}^{2}\right)$. The glaciers are mostly located in the three highest-elevated massifs: Mont Blanc (83 glaciers), Vanoise (174) and Écrins massifs (282). Some small glaciers also exist in the Belledonne, Grandes Rousses and Ubaye massifs (fig. 1), while only glacierets persist in the Mercantour.

The mean altitude at which glaciers terminate in the French Alps is $2,840 \mathrm{~m}$ a.s.l. The lowest altitudes are reached by glaciers of the Mont Blanc massif: the Bossons glacier (1,429m a.s.l.), the Mer de Glace $(1,531 \mathrm{~m}$ a.s.l.) and the Argentière glacier $(1,590 \mathrm{~m}$ a.s.l.). In the Écrins and Vanoise massifs, the lowest frontal altitudes are reached by debris-covered glaciers: respectively

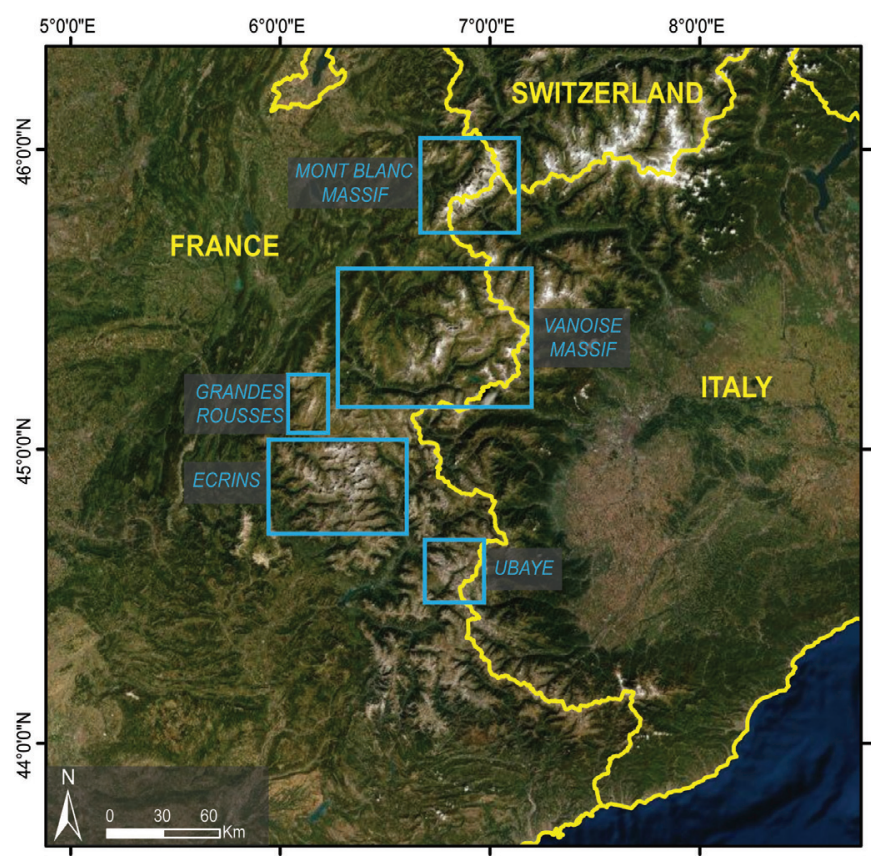

Fig. 1 - Location map: The French Alps and their main glacierized massifs.

Satellite image source: Esri, DigitalGlobe, GeoEye, Earthstar Geographics, CNES/ Airbus DS, USDA, USGS, AeroGRID, IGN, and the GIS User community (Coordinate system: WGS84).

Fig. 1 - Carte de localisation : Les Alpes françaises et leurs massifs englacés. Source de l'image satellite : Esri, DigitalGlobe, GeoEye, Earthstar Geographics, CNES/ Airbus DS, USDA, USGS, AeroGRID, IGN, et la communauté d'utilisateurs GIS (Système de coordonnées: WGS84). 
the Noir glacier $(2,174 \mathrm{~m}$ a.s.l.) and the Pramort glacier $(2,325 \mathrm{~m}$ a.s.1.).

According to Gardent et al. (2014), glaciers have lost about half of their surface area between the end of the LIA and the 2006/2009 period in the Écrins, Vanoise and Mont Blanc massifs. These authors also explain that glacier recession was 2.5 times faster between the 1967-1971 and 2006-2009 periods than between the end of the LIA and 1967-1971, with a decrease in glacier surface area of about $25 \%$ over the more recent period. Due to glacier retreat, Gardent (2014) inventoried 443 new ponds and lakes in proglacial areas since the LIA, of which 227 are over $500 \mathrm{~m}^{2}$. Of these larger water bodies, 14 are located behind potentially unstable dams consisting of non-consolidated morainic material.

By the end of the $21^{\text {st }}$ century, Alpine glaciers are expected to lose about $75 \%$ to $95 \%$ of their volume, depending on greenhouse gas emissions scenarios (Zekollari et al., 2019). In France, detailed projections have been proposed for only two of the largest glaciers: the Argentière and the Mer de Glace in the Mont Blanc massif (Vincent et al., 2019). This study suggests that these glaciers are likely to almost completely disappear before 2100 in the case of the most pessimistic scenario (RCP 8.5), and that the latter would be reduced to about $20 \%$ of its current surface area in a more optimistic scenario (RCP 4.5). No detailed glacier retreat projection has so far been conducted at the scale of the entire French Alps. However, the glacier inventory provided by Gardent et al. (2014) offers the opportunity to predict possible locations of potential GBOs with the GlabTop model (Linsbauer et al., 2012).

\section{Methods and data}

The approach for determining GBOs as possible future lake locations in the French Alps is conducted by first running GlabTop and GlabTop2 models, which use the same basic assumptions but differ by their level of automation. Then, after comparing and compiling results of both models, a morphological analysis is conducted on each predicted GBO to evaluate the level of confidence attributed to the prediction. We also evaluate the predictions by comparing recently formed water bodies and locations of simulated GBOs. Finally, we complete our investigation with a visual analysis of potential GBOs that would possibly have been overlooked by GlabTop approaches.

\subsection{Modelling GBOs with GlabTop and GlabTop2}

The original GlabTop model is a GIS scheme which determines glacier bed topography using glacier outlines, a Digital Elevation Model (DEM) and manually drawn glacier branch lines (Linsbauer et al., 2009; Paul and Linsbauer, 2012). It calculates the ice thickness from surface slope at points sampled from the digitalized branch lines, assuming a relation between the basal shear stress and glacier elevation range as a governing factor of mass turn-over. Then, the ice thickness is subtracted from the original DEM to product a new DEM without glaciers. On this latter DEM, GBOs are delineated by GlabTop and can be interpreted as places for potential futures lakes.

GlabTop2 runs on the same principles but is more appropriate to be applied over large areas as it is fully automatized and does not require manually digitized branch lines on each glacier. Thus, ice thickness is not derived along branch lines but is estimated by the average slope of all gridcells within a certain buffer on each glacier (Frey et al., 2014; Linsbauer et al., 2016). GlabTop2 GBOs are delineated based on modelled ice thickness according to the same procedure as with GlabTop.

We run GlabTop and GlabTop2 with the $25 \mathrm{~m}$ resolution DEM of the French Institute for Geography (IGN), the data basis of which was acquired between 2000 and 2010. As GlabTop2 performs reliable on a DEM resolution between 50 to $100 \mathrm{~m}$, we resampled the input DEM to $50 \mathrm{~m}$ resolution. Glacier outlines were the ones from Gardent et al. (2014) drawn from orthorectified photographs taken between 2004 and 2009. Those are not the most updated contour lines, but they have the advantage to cover recently deglaciated forefield areas where lakes may, or may not, have formed and could be compared with predicted GBOs (see section 3.2). Furthermore, the outlines (2004-2009) fit with the DEM (2000-2010), which is also important point for GlabTop modelling. To run GlabTop, branch lines were manually digitized on each glacier following advices from Paul and Linsbauer (2012), which is from bottom to top and perpendicularly to the contour lines of surface elevation. Each branch line ends about $100 \mathrm{~m}$ from the glacier outline and branch lines have a width interval of $200 \mathrm{~m}$ to $400 \mathrm{~m}$.

To analyse the model results, the outputs of GlabTop and GlabTop2 are combined. Where GBOs are predicted with both models, those from GlabTop2 are removed. The morphometric characterization of predicted GBOs is thus mostly based on those predicted with GlabTop, but in most cases, the location is confirmed with GlabTop2.

\subsection{Evaluation of GlabTop results}

An evaluation of the results was conducted by comparing predicted GBOs with the presence or absence of lakes in most recently deglaciated areas. As GlabTop was applied to glacier outlines collected between 2004 and 2009, it is now possible to use more recent images available on Google Earth to determine whether lakes have formed or not where GBOS had been predicted. Magnin et al. (2020) already carried out such an analysis for the Mont Blanc massif, showing that water bodies have formed in 5 out of the 8 predicted GBOs at retreating glacier margins. In this study, we extend these results to the entire French Alps.

\subsection{Determining the level of confidence for the predicted GBOs}

To determine the level of confidence for each predicted GBO, a morphological analysis based on four criteria defined by Frey et al. (2010) is conducted. This analysis uses Google Earth images and considers [I] the slope angle at predicted GBO, [II] the presence/ absence of a break in slope angle downstream of the predicted GBO, [III] the presence/absence of a bedrock threshold and/or a glacier narrowing at the predicted GBO outlet, and [IV] the presence/absence of a transition between a crevasse-free area and a crevasse field which indicates a transition from compressing to 
Table 1 - Morphological analysis criteria used to determine the level of confidence for the predicted GBOs, following the approach proposed by Magnin et al. (2020).

Table 1 - Les critères de l'analyse morphologique utilisée pour déterminer le niveau de confiance des surcreusements glaciaires prédits, d’après l'approche proposée par Magnin et al. (2020).

\begin{tabular}{|c|c|c|c|c|}
\hline $\begin{array}{l}\text { Criterion } \\
\text { value }\end{array}$ & $\begin{array}{l}\text { [I] Slope angle at } \\
\text { predicted GBOs }\end{array}$ & $\begin{array}{l}\text { [II] Break in } \\
\text { slope angle }\end{array}$ & $\begin{array}{l}\text { [III] Bedrock threshold / } \\
\text { glacier narrowing }\end{array}$ & $\begin{array}{c}{[\text { IV] Transition from no }} \\
\text { crevasse to a field of crevasses }\end{array}$ \\
\hline 0 & $<20 \%<20^{\circ}$ & $<20 \%>5^{\circ}$ & none & none \\
\hline 1 & $>20 \%<20^{\circ}$ & $>20 \%>5^{\circ}$ & & \\
\hline 2 & $>50 \%<20^{\circ}$ & $>50 \%>5^{\circ}$ & & \\
\hline 3 & $>50 \%<15^{\circ}$ & $>50 \%>10^{\circ}$ & & \\
\hline 4 & $>50 \%<10^{\circ}$ & $>50 \%>15^{\circ}$ & & \\
\hline 5 & $>50 \%<5^{\circ}$ & $>50 \%>20^{\circ}$ & obvious & obvious \\
\hline
\end{tabular}

extending ice flow downstream of the predicted GBOs. For each criterion, a value ranging from 0 to 5 is attributed according to its obviousness (tab. 1). The sum of each criterion value is then calculated for each GBO, which can reach a maximum of 20 (four times 5), similar to Magnin et al. (2020).

When one of the criteria cannot be analysed (such as the transition between crevasse-free area and crevasse field in the case of debris covered glaciers) the total value cannot exceed 15 . Then, a percentage of cumulated values relative to the maximum total value is calculated as follows:

$$
\begin{aligned}
& \frac{\sum 3 \text { criteria }}{15} \times 100 \\
& \frac{\sum 4 \text { criteria }}{20} \times 100
\end{aligned}
$$

The third and final step consists in determining a level of confidence from 0 to 5 for each GBO which was defined according to the percentage of cumulated values as follow:

$<10 \%=$ extremly low confidence $(0 / 5)$

$\geq 10 \%<30 \%=$ very low confidence $(1 / 5)$

$\geq 30 \%<50 \%=$ low confidence $(2 / 5)$

$\geq 50 \%<70 \%=$ medium confidence $(3 / 5)$

$\geq 70 \%<90 \%=$ high confidence $(4 / 5)$

$\geq 90 \%=$ very high confidence $(5 / 5)$

This classification is largely based on subjective and qualitative assertions but involves integrative expert judgements related to the basic physics of glacier flow through overdeepened parts of their beds. It represents a strong and independent possibility to assess the degree of uncertainty and confidence with respect to GBOs predicted using numerical model calculations.

\subsection{Visual identification of other potentials GBOs}

Some potential GBOs are not detected by the models, possibly due to the lack of accuracy or precision of the GlabTop input data, notably the DEM, which can smooth the topography and prevent the model from detecting possible breaks in slope angle (Magnin et al., 2020). Furthermore, the GlabTop model does not consider erosionresistant bedrock ridges on lateral slopes and corresponding width- reduction of glacier flow, or spatial patterns of crevasse occurrences which are all important criteria defining potential GBOs. Glacier tongues can also be a limit in GBO-prediction where glacier outlines and DEM do not correspond in detail.

In order to complete the results of GlabTop and GlabTop2 and to compensate the model limits, an additional analysis was performed by visually detecting potential GBOs based on transition from flat to steep glacier surface (criteria [I] and [II]). In the same way as the predicted GBOs, the levels of confidence of those visually detected have also been determined by considering the other criteria. More specifically, a potential GBO is first detected at places where the criteria related to slope angles [I] and [II] are $\geq 3$ as proposed in Magnin et al. (2020), and then the presence/absence of crevasse fields and bedrock threshold is also analysed to classify the GBOs visually detected according to their level of confidence.

\section{Results}

Here we present the GBOs predicted by GlabTop, their main characteristics (location, surface area, depth, volumes, altitude) and the classification of GBOs plausibility based on a morphological analysis. We also evaluate the predicted GBOs by comparing GlabTop outputs with water bodies recently formed in deglaciated areas. Finally, we complete the GlabTop results by visually detecting other potential GBOs with the morphological analysis.

\subsection{Characteristics of the predicted GBOs}

\subsubsection{General features and data sorting}

Predicted GBOs with GlabTop and GlabTop2 have similar locations (fig. 2).

However, GlabTop2 predicts more GBOs than GlabTop, notably at the snout of narrow glacier tongues (fig 3). This is most probably an effect of digitized branch lines in GlabTop.

Part of the GBOs predicted with GlabTop2 have higher values for surface area and mean depth, resulting in correspondingly larger volumes (fig. 4 , tab. 2). The third quartile of the surface area is at $0.11 \mathrm{~km}^{2}$ with GlabTop and at $0.14 \mathrm{~km}^{2}$ with GlabTop2, and the third quartile of the mean depth is at $18 \mathrm{~m}$ with GlabTop and at $18.5 \mathrm{~m}$ with GlabTop2. This explains the higher volumes with GlabTop2 with a third quartile at $3.3 \mathrm{Mm}^{3}$ compared to 

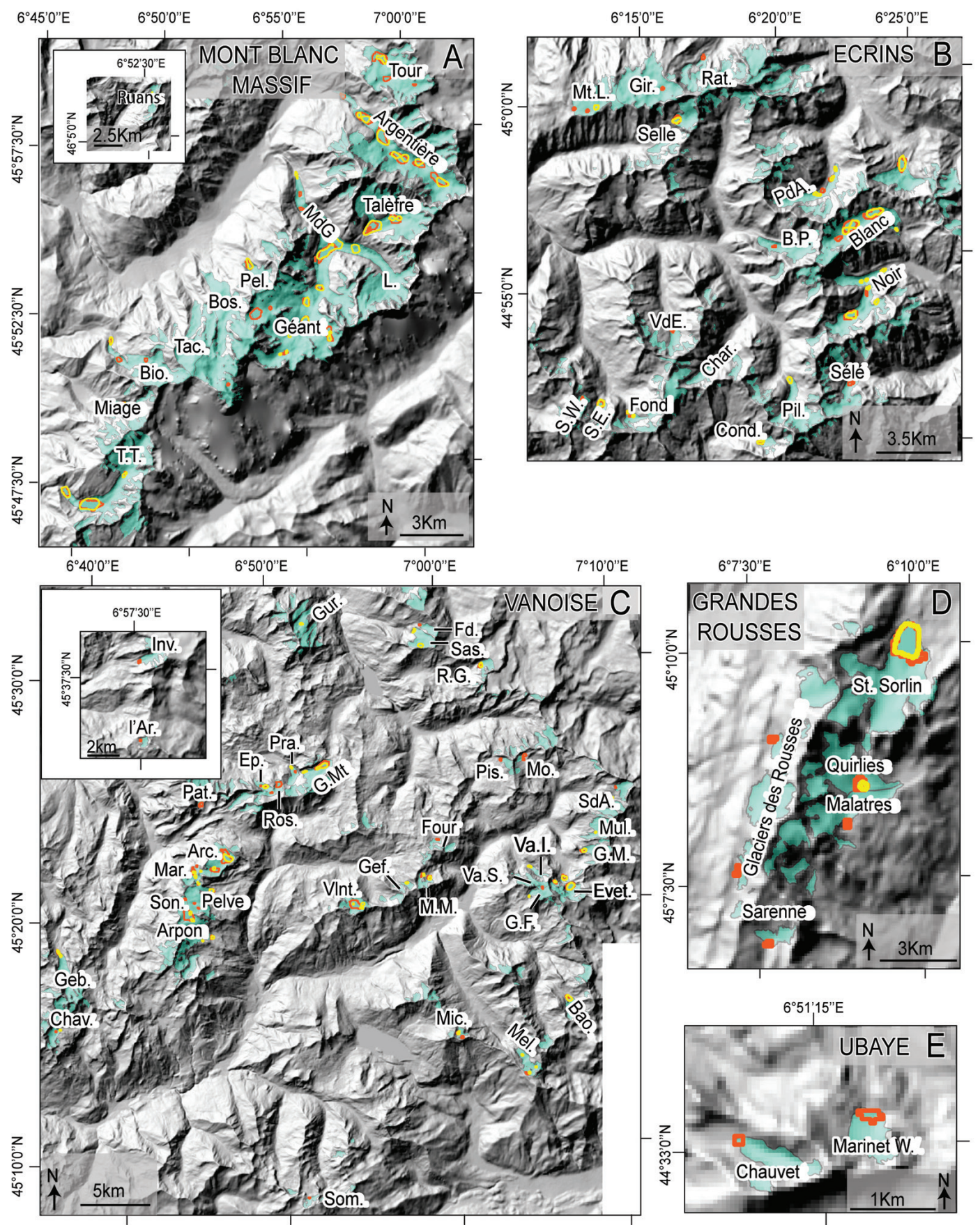

Fig. 2 - Surcreusements glaciaires prédits par GlabTop (lignes jaunes) et GlabTop2 (lignes orange).

A : massif du Mont Blanc (MdG : Mer de Glace ; Pel. : glacier des Pélerins ; L. : glacier de Leschaux ; Bos. : glacier des Bossons ; Tac. : glacier de Taconnaz ; Bio. : glacier de Bionnassay ; T.T. : glacier de Tré la Tête) ; B : massif des Écrins (Mt.L. : glacier du Mont de Lans; Gir. : glacier de la Girose ; Rat. : glacier du Rateau ; PdA : glacier de la Plate des Agneaux ; B.P. : glacier de la Bonne Pierre ; VdE : glacier du Vallon des Êtages ; Char. : glacier du Chardon ; S.W. : glacier Ouest des Sellettes ; S.E. : glacier Est des Sellettes ; Pil. glacier de la Pilatte ; Cond. : glacier des Condamines) ; C: massif de la Vanoise (Inv. : glacier de l'Invernet ; l'Ar. : glacier de l'Argentière; Gur. : glacier de la Gurraz; Fd. : glacier du Fond ; Sas. : glacier de la Sassière ; R.G. : glacier de Rhêmes Golette ; Pra. : glacier de Pramort ; G.Mt. : glacier de la Grande Motte ; Ros. : glacier du Rosolin ; Ep. : glacier de l'Epéna ; Arc. : glacier de l'Arcelin ;Mar. : glacier du Grand Marchet ; Geb. : glacier de Gebroulaz; Chav. : glacier de la Chavière ; Pis. : glacier du Pisaillas ; Mo. : glacier du Montet ; Gef. : glacier du Géfret ; M.M. : glacier du Méan Martin ; Vlnt. : glacier du Vallonnet ; Va.I. : glacier du Vallonnet Inférieur ; Va.S. : glacier du Vallonnet Supérieur ; SdA. : glacier des Sources de l'Arc; Mul. : glacier du Mulinet ; G.M. : glacier du Grand Méan ; Son. : glacier des Sonailles ; Evet. : glacier des Evettes; G.F. : glacier du Grand Fond ; Mic. : glacier de la Roche Michel ; Bao. : glacier du Baounet ; Mel. : glacier de Rochemelon ; Som. : glacier du Sommellier) ; D : massif des Grandes Rousses ; E : massif de l'Ubaye. Système de coordonnées : Lambert 93 / RGF 93.

Fig. 2 - GBOs predicted with GlabTop (yellow outlines) and GlabTop2 (orange outlines).

A: Mont Blanc massif (MdG: Mer de Glace; Pel.: Pélerins glacier; L.: Leschaux glacier; Bos.: Bossons glacier; Tac.: Taconnaz glacier; Bio.: Bionnassay glacier; T.T.: Tré la Tête Glacier); B: Écrins massif (Mt.L.: Mont de Lans glacier; Gir.: Girose glacier; Rat.: Rateau glacier; PdA.: Plate des Agneaux glacier; B.P.: Bonne Pierre glacier; VdE: Vallon des Étages glacier; Char:: Chardon glacier; S.W.: Sellettes glacier West; S.E.: Sellettes glacier East; Pil.: Pilatte glacier; Cond.: Condamines glacier); C: Vanoise massif (Inv.: Invernet glacier; l'Ar.: l'Argentière glacier; Gur.: Gurraz glacier; Fd.: Fond glacier; Sas.: Sassière glacier; R.G.: Rhêmes Golette glacier; Pra.: Pramort glacier; G.Mt.: Grande Motte glacier; Ros.: Rosolin glacier; Ep.: Epéna glacier; Arc.: Arcelin glacier; Mar.: Grand Marchet glacier; Geb.: Gebroulaz glacier; Chav.: Chavière glacier; Pis.: Pisaillas glacier; Mo.: Montet glacier; Gef.: Géfret glacier; M.M.: Méan Martin glacier; Vlnt.: Vallonnet glacier; Va.I.: Vallonnet Inférieur glacier; Va.S.: Vallonnet Supérieur glacier; SdA.: Sources de l'Arc glacier; Mul.: Mulinet glacier; G.M.: Grand Méan glacier; Son.: Sonailles; Evet.: Evettes glacier; G.F.: Grand Fond glacier; Mic.: Roche Michel glacier; Bao.: Baounet glacier; Mel.: Rochemelon glacier; Som.: Sommellier glacier); D: Grandes Rousses massif; E: Ubaye massif. Coordinate system : Lambert 93 / RGF 93. 


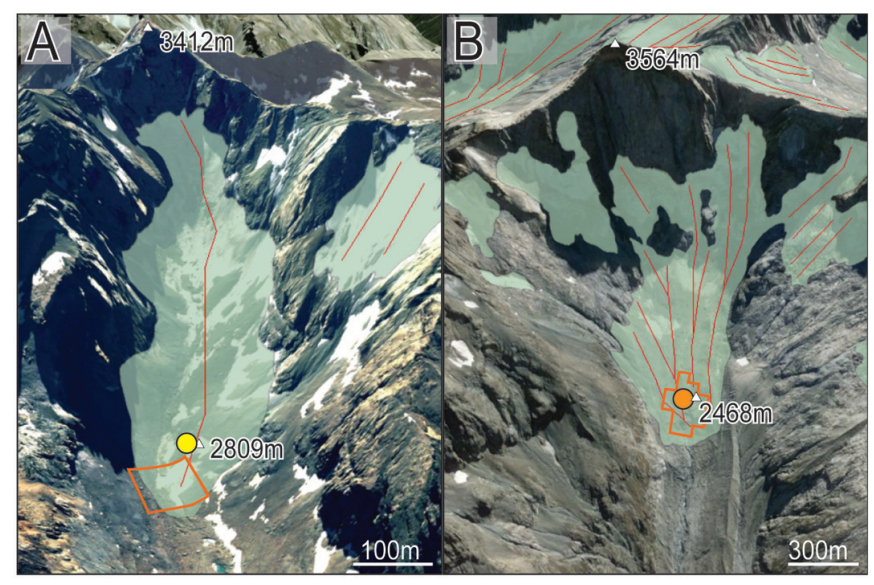

Fig. 3 - Example where only GlabTop2 predicts GBOs at the snout of narrow glacier tongues.

The red lines are the flowlines used for GlabTop among which ice thickness is calculated. The orange polygons are the predicted GBOs with GlabTop2 (the altitudes are expressed in meters a.s.l.). A: Chauvet glacier (Ubaye massif); B: Vallon des Étages glacier (Écrins massif).

Fig. 3 - Exemple de lieux où seulement GlabTop2 prédit un surcreusement glaciaire au front d'une langue glaciaire.

Les lignes rouges sont les lignes de flux utilisées par GlabTop pour calculer l'épaisseur de Glace. Les polygones orange sont les surcreusements sous glaciaires prédits par GlabTop2 (les altitudes sont exprimées en mètres NGF). A : glacier de Chauvet (massif de l'Ubaye); $B:$ glacier $d u$ Vallon des Étages (massif des Écrins).

GlabTop which the third quartile is at $1.7 \mathrm{Mm}^{3}$. However, the median values and most extreme outliers of these variables are slightly more important with GlabTop. The median value of the surface area is at $0.04 \mathrm{~km}^{2}$ with GlabTop and $0.035 \mathrm{~km}^{2}$ with GlabTop2 while the ones of the maximum depth is $25 \mathrm{~m}$ with the former and $17.5 \mathrm{~m}$ with the latter. GlabTop also predicts greater maximum depth for more than half of the predicted GBOs, but the most extreme outliers of this variable are found with GlabTop2. Such differences are discussed in more detail below (see section 5.1).

Predicted GBOs are most abundant in the Vanoise massif but the most extensive and most voluminous ones are found in the Mont Blanc massif (tab. 2). Maximum depths differ between the two GlabTop versions and from massif to massif. A maximum-depth value exceeding $100 \mathrm{~m}$ is produced by both model versions in the Mont Blanc massif, while in the Vanoise and Écrins massifs it only results from GlabTop2.
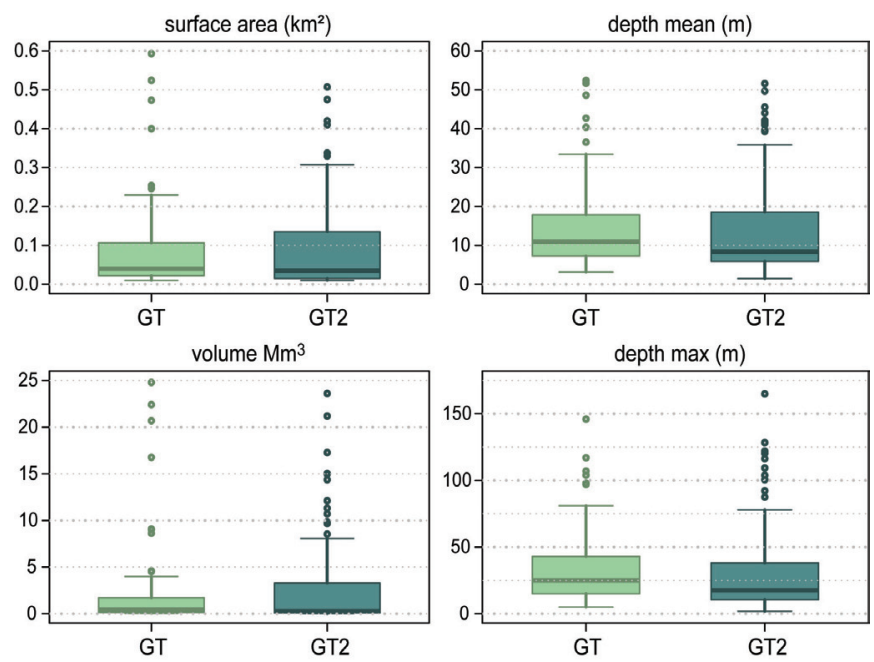

Fig. 4 - Comparison between GlabTop and GlabTop2 of the surface area, max depth, mean depth, and volume of the calculated GBOs.

Fig. 4 - Comparaison de la superficie, de la profondeur maximum, de la profondeur moyenne et du volume des surcreusements glaciaires entre GlabTop et GlabTop2.

When analysing predicted GBO morphometrics in more detail, it has to be kept in mind that depths and volumes of GBOs tend to be generally underestimated (Magnin et al., 2020). Nevertheless, those morphometrics can be used to compare GBOs with each other. In order to compare general GBO characteristics for different mountain ranges, we combine the outputs of GlabTop and GlabTop2 and suppress duplicated GBOs at individual sites and keep only one per location. We thereby give priority to the GlabTop output. A total of 139 GBOs $\left(>0.01 \mathrm{~km}^{2}\right)$ is finally found for the entire French Alps, including 40 GBOs in the Mont Blanc massif, 60 in the Vanoise, 30 in the Écrins, 6 in the Grandes Rousses, 2 in the Ubaye and 1 in the Ruans massifs. In the Mont Blanc massif, it is necessary to specify that when comparing our GlabTop outputs with those of Magnin et al., (2020), 6 GBOs were not identified by Magnin et al. (under the Tour, Bossons, Mer de glace, Géant and Bionassay glaciers), while five others

Table 2 - Comparison of the predicted GBOs characteristics with GlabTop (GT) and GlabTop2 (GT2) for each massif of the French Alps. Table 2 - Comparaison des surcreusements glaciaires prédits avec GlabTop (GT) et GlabTop2 (GT2) pour chaque massif des Alpes françaises.

\begin{tabular}{|c|c|c|c|c|c|c|c|c|c|c|c|c|c|c|c|c|}
\hline & \multicolumn{2}{|c|}{$\begin{array}{l}\text { Aig. Rouges - } \\
\text { Ruan }\end{array}$} & \multicolumn{2}{|c|}{ Ecrins } & \multicolumn{2}{|c|}{$\begin{array}{l}\text { Grandes } \\
\text { Rousses }\end{array}$} & \multicolumn{2}{|c|}{ Mont Blanc } & \multicolumn{2}{|c|}{$\begin{array}{c}\text { Thabor - } \\
\text { Aig. D'Arves }\end{array}$} & \multicolumn{2}{|c|}{ Ubaye } & \multicolumn{2}{|c|}{ Vanoise } & \multicolumn{2}{|c|}{ French Alps } \\
\hline & GT & GT2 & GT & GT2 & GT & GT2 & GT & GT2 & GT & GT2 & GT & GT2 & GT & GT2 & GT & GT2 \\
\hline $\begin{array}{l}\text { Number of } \\
\text { GBOs }\end{array}$ & 1 & - & 20 & 22 & 2 & 6 & 28 & 33 & 1 & - & - & 2 & 39 & 42 & 91 & 105 \\
\hline $\begin{array}{l}\text { Total surface } \\
\text { area }\left(\mathrm{km}^{2}\right)\end{array}$ & 0.02 & - & 1.29 & 1.52 & 0.26 & 0.04 & 4.21 & 4.73 & 0.02 & - & - & 0.03 & 2.17 & 3.5 & 7.97 & 10.19 \\
\hline $\begin{array}{l}\text { Max depth } \\
\quad(\mathrm{m})\end{array}$ & 15.0 & - & 47.0 & 128.4 & 81.0 & 39.0 & 146.0 & 122.0 & 15.0 & - & - & 22.8 & 75.0 & 165.0 & 146.0 & 165.0 \\
\hline $\begin{array}{l}\text { Mean depth } \\
(\mathrm{m})\end{array}$ & 8.1 & - & 11.6 & 13.0 & 20.8 & 9.7 & 20.2 & 18.7 & 8.1 & - & - & 11.3 & 11.3 & 11.9 & 13.3 & 12.9 \\
\hline $\begin{array}{l}\text { Total volume } \\
\qquad\left(\mathrm{Mm}^{3}\right)\end{array}$ & 0.1 & - & 18.4 & 42.4 & 9.1 & 6.5 & 131.7 & 137.2 & 0.1 & - & - & 0.4 & 34.0 & 89.3 & 193.4 & 275.3 \\
\hline
\end{tabular}


had been predicted contrary to our previous results (under the Géant, Mer de Glace, Bossons and Bionassay glaciers). This could be explained by the different DEM and branch lines sets used in the two studies.

\subsubsection{Surface areas of predicted GBOs}

The predicted GBOs represent a total surface area of $9.48 \mathrm{~km}^{2}$, about $3.5 \%$ of the glacier surface area. Half of it is in the Mont Blanc massif $\left(4.81 \mathrm{~km}^{2}, 4.7 \%\right.$ of the glacier surface area in the Mont Blanc massif), about $29 \%$ in the Vanoise massif $\left(2.74 \mathrm{~km}^{2}, 3 \%\right.$ of the glacier surface area in Vanoise massif) and $16 \%$ in the Écrins massif $\left(1.56 \mathrm{~km}^{2}, 2.3 \%\right.$ of the glacier surface area in Écrins massif; tab. 3).

The largest calculated GBOs, that are in the Mont Blanc massif (fig. 5), would be at the confluence of the Leschaux and Tacul glacier (top of the Mer de Glace), and at the Tré la Tête and Talèfre glaciers, with an area of $0.6 \mathrm{~km}^{2}, 0.52 \mathrm{~km}^{2}$ and $0.47 \mathrm{~km}^{2}$ respectively. In the Vanoise massif, the two GBOS that would have the largest surface area are under the Arcelin glacier $\left(0.25 \mathrm{~km}^{2}\right)$ and the Evettes glacier $\left(0.21 \mathrm{~km}^{2}\right)$. In the Écrins massif, the two largest GBOs are both found under the Blanc glacier with a surface area of $0.23 \mathrm{~km}^{2}$ and $0.22 \mathrm{~km}^{2}$ respectively. Finally, another relatively large GBOs was predicted under the Saint Sorlin glacier with a surface area of $0.25 \mathrm{~km}^{2}$ in the Grandes Rousses massif.

Table 3 - Number and morphological characteristics of the predicted GBOs in each massifs of the French Alps when combining GlabTop and GlabTop2 results and supressing the duplicated GBOs.

Table 3 - Nombre et caractéristiques morphologiques des surcreusements glaciaires prédits dans chaque massif des Alpes françaises, en combinant les résultats de GlabTop et GlabTop2 et en supprimant les surcreusements en double.

\begin{tabular}{|c|c|c|c|c|c|c|c|}
\hline & $\begin{array}{c}\text { Aig. Rouges - } \\
\text { Ruan }\end{array}$ & Ecrins & $\begin{array}{l}\text { Grandes } \\
\text { Rousses }\end{array}$ & Mont Blanc & Ubaye & Vanoise & $\begin{array}{c}\text { Total } \\
\text { French Alps }\end{array}$ \\
\hline Number of GBOs & 1 & 30 & 6 & 40 & 2 & 60 & 139 \\
\hline Mean surface area $\left(\mathrm{km}^{2}\right)$ & 0.02 & 0.05 & 0.05 & 0.12 & 0.02 & 0.05 & 0.07 \\
\hline Total surface area $\left(\mathrm{km}^{2}\right)$ & 0.02 & 1.56 & 0.31 & 4.81 & 0.04 & 2.74 & 9.48 \\
\hline Mean volume $\left(\mathrm{Mm}^{3}\right)$ & 0.1 & 0.7 & 1.6 & 3.6 & 0.2 & 0.7 & 1.6 \\
\hline Total volume $\left(\mathrm{Mm}^{3}\right)$ & 0.1 & 20.6 & 9.5 & 145.5 & 0.4 & 41.3 & 217.4 \\
\hline
\end{tabular}
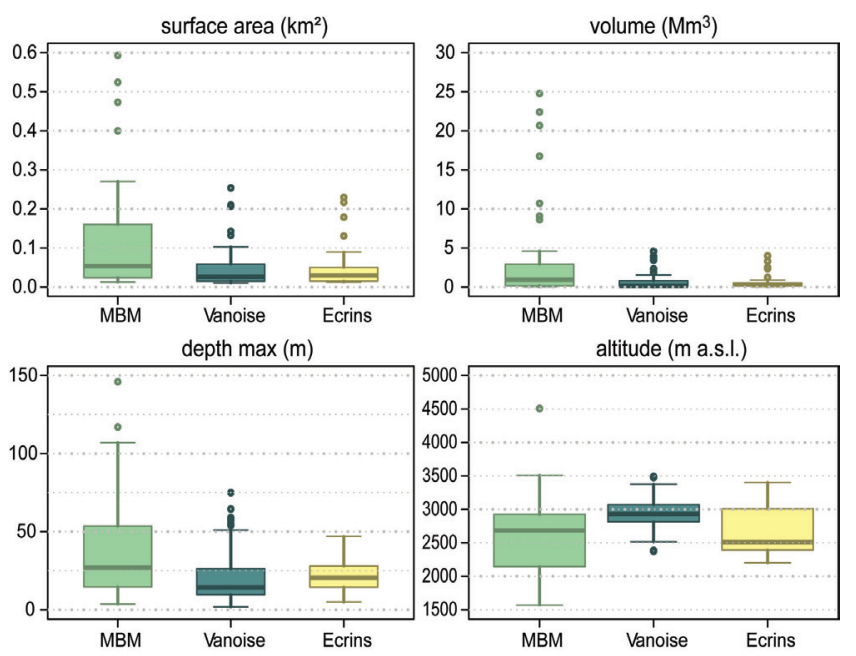

Fig. 5 - Comparison of the surface, volume and depth of the GBOs predicted by GlabTop between the Mont Blanc massif (MBM), the Vanoise massif and the Écrins massif.

Fig. 5 - Comparaison de la superficie, du volume et de la profondeur des surcreusements glaciaires prédits par GlabTop entre le massif du Mont Blanc (MBM), la Vanoise et les Écrins.

\subsubsection{Depth of predicted GBOs}

On average, the calculated GBOs are deeper in the Mont Blanc massif (fig. 5), and the deepest ones reach $146 \mathrm{~m}$ and $117 \mathrm{~m}$ respectively and, are both under the Argentière glacier. Another deep GBOs is found under Tré la Tête glacier (107m).

In the Vanoise massif, the deepest GBOs are under Evettes glacier $(75 \mathrm{~m})$ and Rosolin glacier $(65.5 \mathrm{~m})$. In the Écrins massif, the deepest GBOs are under the Noir glacier $(47 \mathrm{~m})$ and the Blanc glacier (45m). Lastly, the GBO under the Saint Sorlin Glacier in the Grandes Rousses massif is deeper than the ones in the Écrins and Vanoise with $81 \mathrm{~m}$.

\subsubsection{Volume of predicted GBOs}

The total volume of the predicted GBOs is $217.4 \mathrm{Mm}^{3}, 67 \%$ of which $\left(145.5 \mathrm{Mm}^{3}\right)$ is in the Mont Blanc massif, $19 \%\left(41.3 \mathrm{Mm}^{3}\right)$ in the Vanoise massif and $9 \%\left(20.6 \mathrm{Mm}^{3}\right)$ in the Écrins massif (tab. 3). The GBOs with the higher volumes are mostly found in the Mont Blanc massif (fig. 5) such as those under the Talèfre glacier $\left(24.8 \mathrm{Mm}^{3}\right)$, the Tré la Tête glacier $\left(22.4 \mathrm{Mm}^{3}\right)$ and the Argentière glacier $\left(20.7 \mathrm{Mm}^{3}\right)$. In the same way as the surface area, the most voluminous GBOs in the Vanoise are those located under the Arcelin and Evette glacier $\left(4.6 \mathrm{Mm}^{3}\right.$ and $4.5 \mathrm{Mm}^{3}$ respectively). In the Écrins massif, the most voluminous GBOs are under the Glacier Blanc $\left(4 \mathrm{Mm}^{3}\right)$ and the Arsine Glacier $\left(3.3 \mathrm{Mm}^{3}\right)$ and, are both less voluminous than the one under the Saint Sorlin glacier (Grandes Rousses massif, 9 $\mathrm{Mm}^{3}$ ).

\subsubsection{Altitude of the predicted GBOs}

The GBOs of the Vanoise massif are generally located at a higher altitude than in the other massifs, with a median value at $3,000 \mathrm{~m}$ a.s.l., and many predicted GBOs are in the upper part of ice-cap shaped glaciers, such as the Pelve and the Arpon glaciers which have two GBOs at an altitude of 3,491m a.s.l. and 3,475m a.s.l. respectively. 
In the Écrins massif, GBOs are generally predicted at altitudes lower by $500 \mathrm{~m}$, with a median value at $2,500 \mathrm{~m}$ a.s.l. Half of the $30 \mathrm{GBO}$ predicted in this massif are thus gathered between 2,200 and 2,500m a.s.l., half of the $40 \mathrm{GBO}$ predicted in the Mont Blanc massif are spread between 1,750 and 2,750m a.s.l., and half of the $60 \mathrm{GBOs}$ predicted in the Vanoise massif are found between 2,500 and 3,000m a.s.l.. The least and most elevated GBOs are found in the Mont Blanc massif at respectively $1,570 \mathrm{~m}$ a.s.l. (Mer de Glace) and 4,507m a.s.l. (Bossons glacier), in coherence with glacier distributions.

\subsection{Morphological analysis and level of confidence of GBOs}

Among the 139 predicted GBOs, 4 cumulate all criteria favouring their existence (see section 3.3) and are thus characterized by a very high confidence ( $100 \%$ of criteria are fulfilled). In addition, $28 \mathrm{GBO}$ have a high confidence and 27 have a medium confidence. Finally, 47 have a low confidence, 31 a very low confidence, and only two predicted GBOs are not plausible with an extremely low confidence (fig. 6). No statistical relationship was found between the level of confidence and GBOs morphometrics but none of the larger or deeper GBO has low level of confidence. The deepest GBO (Argentière glacier) and the most voluminous one (Talèfre glacier) are both characterised by high confidence.

The Mont Blanc massif gathers 16 of the 32 GBOs with a high and very high confidence. Among the least likely GBOs (low, very low and extremely low confidence), $73 \%$ are located in the Vanoise massif.

In the Mont Blanc massif, the GBOs most likely to exist (very high confidence) are under the Talèfre, Tré la Tête and Bionnassay glaciers, and some GBOs under the Mer de Glace, Miage, Argentière and Tour glaciers have also a high confidence. In the Vanoise massif, the GBOs with the higher level of confidence are located under the Evettes and the Rosolin glaciers (high confidence). The GBOs under the Pramort, the Epéna, and the Gébroulaz glaciers have a medium confidence. In the Écrins massif, the most plausible GBOs are under the Selette, the Condamines and the Blanc glaciers (high confidence).

In the Grandes Rousses massif, the most voluminous GBO under the
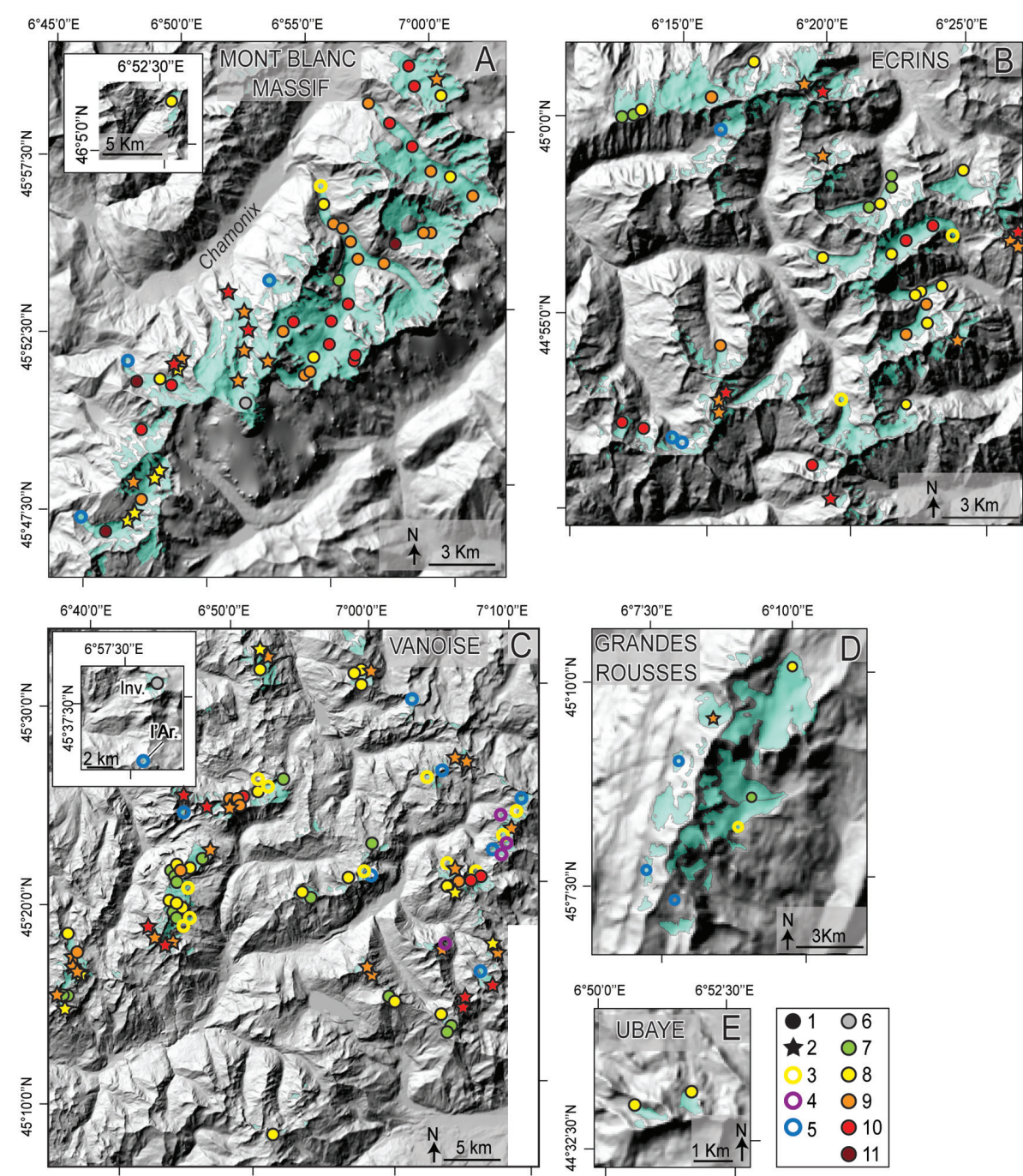

Fig. 6 - Level of confidence of the GBOs predicted by GlabTop and GlabTop2, GBOs visually detected and presence/absence of water body at predicted GBOs.

A: Mont Blanc massif; B: Écrins massif; C: Vanoise massif; D: Grandes Rousses massif; E: Ubaye massif. (Coordinate system: Lambert 93 / RGF 93). 1. GBO predicted by GlabTop; 2 . GBO visually detected; 3 . Absence of water body at predicted GBO; 4. Water body at predicted $\mathrm{GBO}<0.01 \mathrm{~km}^{2} ; 5$. Water body at predicted $\mathrm{GBO}$ in recently deglaciated area; 6 . Extremely low confidence; 7 . Very low confidence; 8. Low confidence; 9. Medium confidence; 10. High confidence; 11. Very high confidence.

Fig. 6 - Niveaux de confiance des surcreusements glaciaires prédits par GlabTop et GlabTop2, surcreusements détectés visuellement et présence/absence de surcreusements dans les surcreusements détectés.

A : massif du Mont Blanc; $B$ : massif des Écrins; $C$ massif de la Vanoise; $D$ : massif des Grandes Rousses; $E$ : massif de l'Ubaye. (Système de coordonnées Lambert 93 / RGF 93). 1. Surcreusement prédit par GlabTop ; 2. Surcreusement détecté visuellement ; 3. Absence de plan d'eau dans le surcreusement prédit $G B O ; 4$. Présence de lac ou plan d'eau dans un surcreusement prédit par GlabTop $<0.01 \mathrm{~km}^{2}$; 5. Présence de lac ou plan d'eau dans les secteurs récemment désenglacés; 6 . Niveau de confiance extrêmement bas ; 7. Niveau de confiance très bas ; 8. Niveau de confiance bas; 9 . Niveau de confiance moyen; 10. Niveau de confiance élevé; 11. Niveau de confiance très élevé
Saint Sorlin glacier $\left(9 \mathrm{Mm}^{3}\right)$ has a low level of confidence. Indications from direct field measurements (geophysics, boreholes) of a possibly overdeepened trough as compiled by Le Meur and Vincent (2003) show that ice thickness reached about $110 \mathrm{~m}$ in 1998 at this location and that another GBO (not predicted by GlabTop model runs) may actually exist farther upstream. For the one predicted with GlabTop beneath the present snout of the Saint Sorlin glacier, the absence of a clear bedrock threshold and a marked break in slope explains 

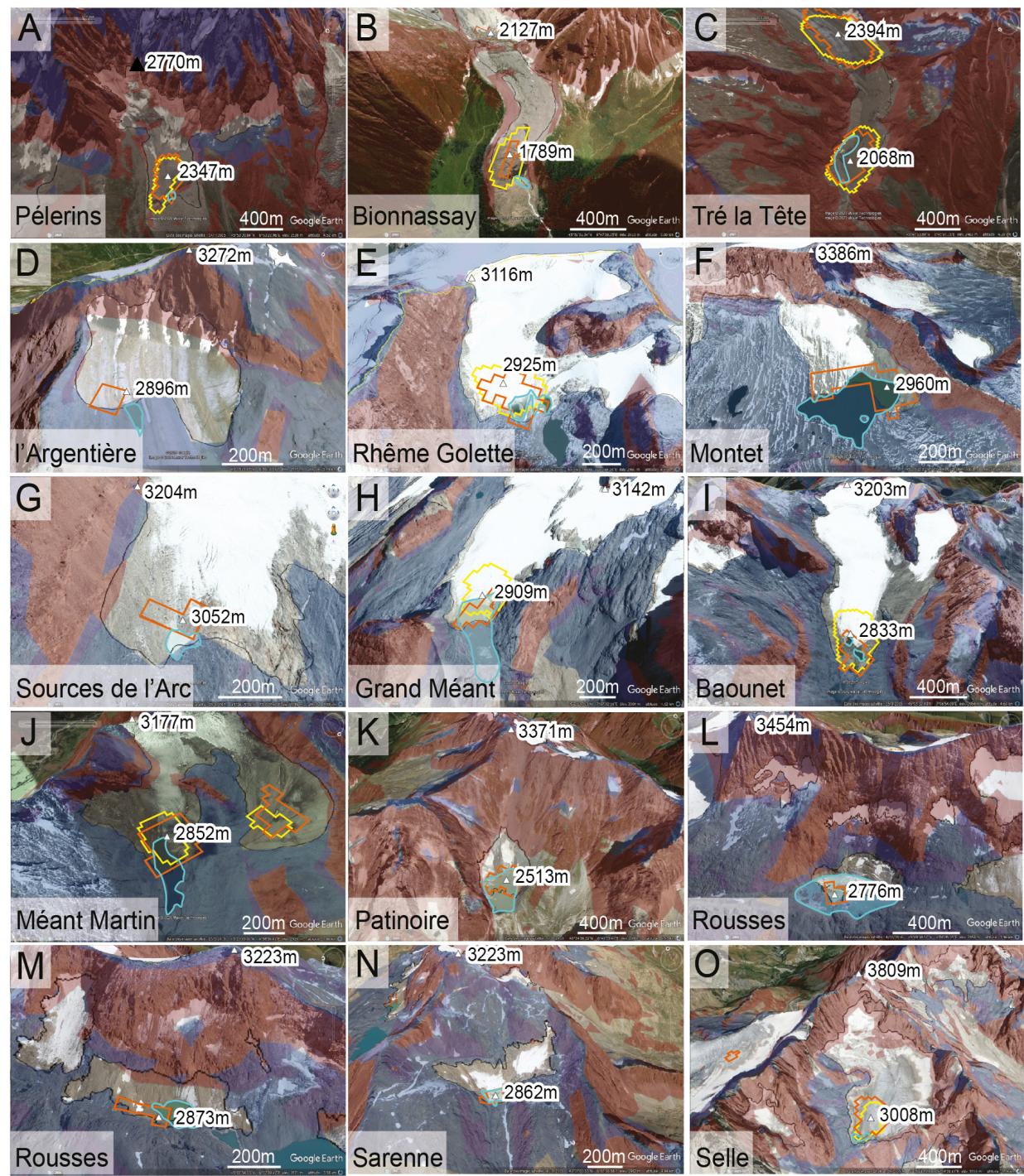

Fig. 7 - Visible new water bodies in recently deglaciated areas where GlabTop and GlabTop2 predicted a GBO.

Red areas: slope $>30^{\circ}$; blue areas : permafrost favourability index $>0.5$ (Marcer et al., 2017) for the slopes $<35^{\circ}$ and permafrost favourability index $>0.5$ (Boeckli et al. 2012) for the slopes $>35$; black lines : glacier contour 2004-2009 (Gardent et al., 2014); light blue lines: visible lake or water bodies limits; Google Earth images, the altitudes are expressed in meters a.s.l. A-C: Mont Blanc massif; D-K: Vanoise massif; L-N: Grandes Rousses massif; O-P: Écrins massif.

Fig. 7 - Lacs ou plans d'eau visibles dans les secteurs récemment désenglacés où GlabTop et GlabTop2 ont prédit des surcreusements glaciaires.

Zones rouges: pente $>30^{\circ}$; zones bleues : indice de permafrost $>0.5$ (Marcer et al., 2017) pour les pentes $<35^{\circ}$, et indice de permafrost $>0.5$ (Boeckli et al. 2012) pour les pentes $>35^{\circ}$; lignes noires : contours des glaciers 2004-2009 (Gardent et al., 2014); lignes bleu clair : limites des lacs et plans d'eau; images de Google Earth, les altitudes sont exprimées en mètres NGF. A-C : le massif du Mont Blanc; $D-K$ le massif de la Vanoise ; L-N : le massif des Grandes Rousses; O-P : le massif des Écrins.

its rather low level of confidence. The already existing small water bodies in front of the present ice margin had developed during the past decades above a rather weakly marked bedrock threshold and corresponding somewhat smooth break in slope.

\subsection{Evaluation of predicted GBOs with water bodies in recently deglaciated ice-marginal areas}

GBOs were predicted using glacier outlines drawn from glacier inventory data acquired between 2004 and 2009 and a corresponding DEM acquired between 2000 and 2010. Since that time, glacier retreat has continued at a fast rate and thereby exposed areas where GBOs had been predicted within but close to the former ice margin. This development makes it possible to investigate sites of predicted GBOs with respect to the questions whether (i) the specific overdeepened topography has been realistically predicted, and (ii) water bodies indeed developed (fig. 7) or not (fig. 9). As mentioned before, the second question involves aspects (drainage, permeability, sediment input) beyond general topographic conditions. It must be kept in mind that the applied slope averaging near flat glacier margins is delicate as it involves topographic information from slightly outside the ice margin. Moreover, the assumption of a constant basal shear stress breaks down for retreating and decaying glaciers with wedge-like marginal ice geometries causing basal shear stresses to decrease towards zero. This effect leads to a systematic overestimation of ice thicknesses towards the ice margin of retreating glaciers and, hence, tends to produce artefacts of adverse slopes. In fact, some of the perennial surface ice bodies from the used glacier inventory are, or have become, extremely small, often disintegrating and collapsing ice remains (e.g., Evettes and Méan Martin) (fig. 9E, G) at the very limits of the term and concept "glacier" 


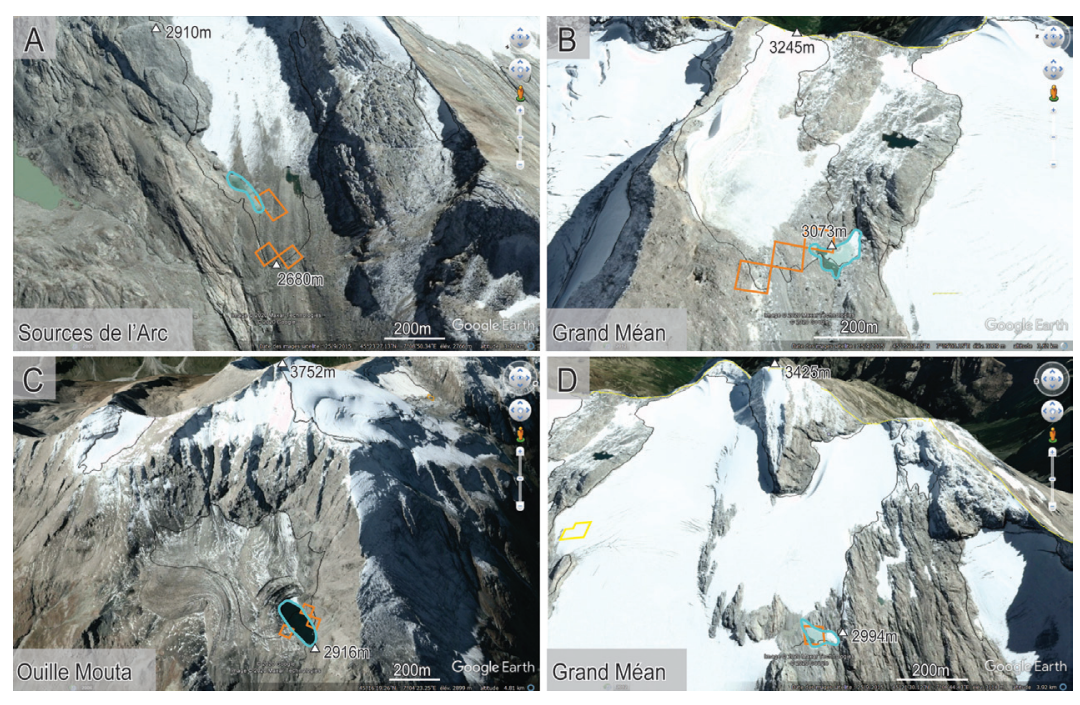

Fig. 8 - Visible new water bodies in recently deglaciated areas where GlabTop and GlabTop2 predicted a $\mathrm{GBO} \leq 0.01 \mathbf{k m}^{2}$.

Black lines: glacier contour 2004-2009 (Gardent et al., 2014); light blue lines: visible lake or water bodies limits; Google Earth images, the altitudes are expressed in meters a.s.l. A: Sources de l'Arc glacier; B: Grand Méan glacier; C: Ouille Mouta glacier; D: Grand Méan glacier.

Fig. 8 - Lacs ou plans d'eau visibles dans les secteurs récemment désenglacés où GlabTop et GlabTop2 ont prédit des surcreusements glaciaires GBO $\leq 0.01 \mathrm{~km}^{2}$.

Lignes noires : contours des glaciers 2004-2009 (Gardent et al., 2014); lignes bleu clair : limites des lacs et plans d'eau images de Google Earth, les altitudes sont exprimées en mètres NGF. A : Glacier des Sources de l'Arc ; B : Glacier du Grand Méan ; C : Glacier d'Ouille Mouta ; D : Glacier du Grand Méan.
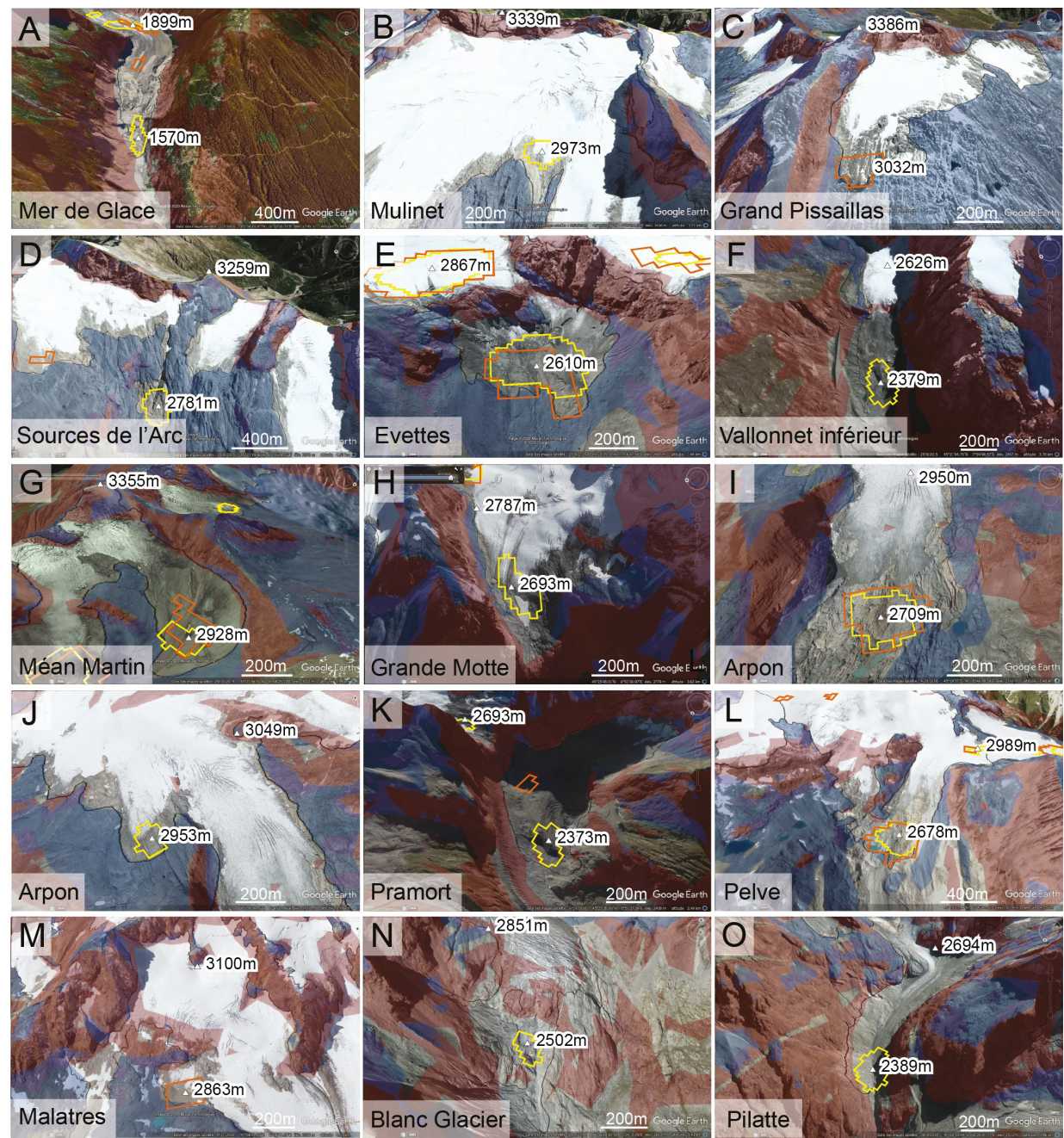

Fig. 9 - Absence of water bodies in recently deglaciated areas where GlabTop and GlabTop2 predicted a GBO.

(Red areas: slope $>30^{\circ}$; blue areas: permafrost favourability index $>0.5$ (Marcer et al., 2017) for the slopes $<35^{\circ}$ and permafrost favourability index $>0.5$ (Boeckli et al. 2012) for the slopes $>35^{\circ}$; black lines: glacier contour 2004-2009 (Gardent et al., 2014); Google Earth images, the altitudes are expressed in meters a.s.l. A: Mont Blanc massif; B-L Vanoise massif; M: Grandes Rousses massif; $\mathrm{N}-\mathrm{O}$ : Écrins massif.

Fig. 9 - Absence de lacs ou de plan d'eau dans les secteurs récemment désenglacés où GlabTop et GlabTop2 ont prédit des surcreusements glaciaires.

(Zones rouges: pente $>30^{\circ}$; zones bleues indice de permafrost $>0.5$ (Marcer et al., 2017) pour les pentes $<35^{\circ}$, et indice de permafros $>0.5$ (Boeckli et al. 2012) pour les pentes $>35^{\circ}$, lignes noires : contours des glaciers 2004-2009 (Gardent et al., 2014); images de Google Earth, les altitudes sont exprimées en mètres NGF. A le massif du Mont Blanc; B-L : la Vanoise; $M$ les Grandes Rousses; N-O : les Écrins.

(e.g., Sources de l'Arc glacier) (fig. 9D). A good number of GBOs are still only partially exposed (e.g., Tré la Tête, Rhême Golette, Grand Méan, Grande Motte, respectively Figure 7C, E, H, 9H).

With few exceptions (for instance, Blanc Glacier) (fig. 9N), the predicted GBOs indeed indicate flat to overdeepened parts of formerly ice-covered topography. In cases, the location of the predicted GBO seems to be small or vague (e.g., Mulinet) (fig. 9B), spatially dislocated (e.g., Malatres; fig 9M) or to have a rough surface in bedrock (e.g., Arpon, Pelve) (fig. 9I, L) or coarse debris (e.g., Tré la Tête, Mer de Glace) (fig. 7C, 9A) with sometimes small ponds existing in correspondingly small topographic depressions (e.g., Méan Martin, Arpon, Pelve) (fig G, I, L). Small to medium-size water bodies and lakes have continued to form (e.g., Montet, Grand Méan) (fig. 7F, H) or newly started to form (e.g., Rhême Golette) (fig. 7E) at 17 sites (fig. 6-7). They can be found at or 
below the snout of the Bionassay, Tré la Tête and Pélerins glaciers in the Mont Blanc massif (fig. 7A-C), downstream of the Selle glacier and the Fond glacier in the Écrins massif (fig. 7O-P) and 3 others in the Grandes Rousses massif downstream of the Rousses glacier and Sarenne glacier (fig. 7L-N). In the Vanoise massif, 8 lakes are already visible (fig. 7D-K), as at the front of the Montet, the Grand Méan and the Patinoire glaciers (fig. 7F, 7H, 7K).

Among these 17 water bodies, 11 have medium, high and very high confidence $(\geq 3 / 5)$, such as the one at the Fond glacier in the Écrins massif for example (fig. 7P). The others have a low confidence ( $\leq$ 2) notably because criteria [II] and [III] (break in slope and bedrock threshold) are not fulfilled. In these cases, water bodies are rather small and shallow, if not almost inexistent as this is the case on the Baounet glacier margin (fig. 7I), where only small water bodies are formed in bedrock hollows, but not as voluminous as the GBOs predicted by GlabTop. Furthermore, some lakes are formed in morainic material such as at l'Argentière glacier (Vanoise massif) (fig. 7D) where the newly formed water body in a local depression of a gently inclined debris slope is displaced with respect to the predicted GBO. It may not turn into a perennial lake, as it looks very shallow, and may drain with changes in the bottom and front material permeability (Haeberli et al., 2001). This is also the case for the Pélerins glaciers (Fig. 7A) as already discussed by Magnin et al. (2020).

In the Grandes Rousses massif, 3 lakes have already started to form in the predicted GBOs (fig. 7L-N), including 2 on the Rousses glacier that is on the west side of the massif where the staircase-like counter slopes form permanent dams that have favoured lake formation (Fig. 7L-M). It has to be noted that only the predicted GBOs $\geq 0.01 \mathrm{~km}^{2}$ are analysed here. However, recently formed pounds or water bodies are also observed in predicted GBOs $<0.01 \mathrm{~km}^{2}$ such as at the snouts of the Sources de l'Arc, the Grand Méan and the Ouille Mouta glaciers (fig 6, 8). While those at the Grand Méan glacier are $<0.01 \mathrm{~km}^{2}$, the one at Sources de l'Arc glacier, which currently reaches $0,005 \mathrm{~km}^{2}$, is partly covered by the glacier and may grow in the future. The one at the snout of the debris-covered Ouille Mouta glacier is already $>0,02 \mathrm{~km}^{2}$ and may also continue growing.

In 15 recently deglaciated GBOs no lake formation is observed (fig. 9AO). One of them is in the Mont Blanc massif, 11 are found in the Vanoise massif, two in the Écrins massif and one exists in the Grandes Rousses massif. In most cases, the absence of water bodies can be explained by a lack of a marked bedrock threshold downstream of the predicted GBO, by a slope that is too steep or by sediment infilling. A large majority (12) of these 15 GBOs have a low and very low level of confidence. Two of them at the front of the Pramort (fig. 9K) and Pilatte (fig. 9O) glaciers have a medium confidence. For both cases, surface slope is relatively steep and, thus, not favourable for water retention. At the Pilatte glacier, a water stream washes out the supplied sediments and uncovers the bedrock below, showing that there is no overdeepening. At the Pramort glacier, despite the presence of a bedrock threshold downstream, no lake has formed and the glacier forefield is a sediment filled floodplain. At the front of the Grande Motte (fig. 9H) glacier, the GBO has a high confidence as it fills criteria [II] and [III], but similarly to the Pilatte glacier, the slope angle $>10^{\circ}$ did not favour water or sediment retention. Sometimes, water bodies are observed but could not become perennial lakes such as in front of Vallonnet Inférieur glacier (fig. 9F), where water is accumulating superficially in morainic material at predicted GBO in the same way as the Pramort glacier, the forefield of the debris-covered
Vallonet Inferieur glacier is turning into a sediment-filled floodplain.

This preliminary analysis indicates that predicted GBOs are realistic in most cases with higher confidence levels from morphological criteria but that failures also exist, especially in cases with lower confidence levels. Such failures primarily relate to specific geometries (wedge type ice margins) of extremely small, disintegrating and collapsing remains of surface ice and to heavily debris-covered parts of glaciers with their specific imbalance and sediment input. A good number of smaller to larger water bodies have indeed formed or continued to form in realistically predicted GBOs. Only smallest water bodies seem to have come into existence where no GBOs were predicted, however, the case of the Source de l'Arc glacier (fig. 8A) and more specifically the Ouille Mouta glacier (fig. 8C) show that large water bodies may form where only insignificant GBOs are predicted. Drainage of exposed GBOs through deep-cut gorges was not evident in any case and seems to be an exception rather than a rule.

\subsection{Potential GBOs visually detected}

In addition to potential GBOs automatically detected with GlabTop and GlabTop2, 58 GBOs have been visually detected by analysing glacier morphologies with the four criteria used to assess predicted GBOs plausibility. 30 of them have been found in the Vanoise massif, 15 in the Mont Blanc massif, 12 others in the Écrins massif and 1 in the Grandes Rousses massif (fig. 6). One GBO only visually detected by Magnin et al. (2020) on the Bionnassay glacier (Mont Blanc massif) was eventually also predicted by GlabTop2 in this study.

According to the morphological analysis, one of these visually detected GBOs in the Écrins massif has a very high confidence. In addition, 13 of them have high confidence and 33 have a medium confidence, and they are all in the Écrins, Grandes Rousses, Vanoise or Mont Blanc massifs. Finally, 11 GBOs visually detected have a low confidence.

\section{Discussion}

\subsection{Strengths and limitations in the method}

Previous work conducted on the Mont Blanc massif compared 20 profiles of Ice Penetrating Radar (IPR) measurements (Rabatel et al., 2018) and seismic measurements (Vincent and Moreau, 2016) acquired on the Argentière glacier to GlabTop results (Magnin et al., 2020). This comparison confirmed that - despite large uncertainties in absolute values of estimated ice thicknesses - the locations of predicted GBOs as topological units defined by spatial patterns rather than absolute values of ice thickness - were generally robust. The morphological analysis, however, remains necessary to assess the level of plausibility of the numerical predictions. Our study confirms these results (see section 4.5) but also points out the relevance of combining various methods, including fully or semi-automated detection approaches such as with GlabTop2 and GlabTop, morphological analysis and visual detection. All these approaches have their respective advantages and drawbacks and can, therefore, provide different but also complementary results. Differences in the GBO morphometrics produced by GlabTop and GlabTop2 can sometimes be considerable and, can be explained by the fact that GlabTop2 calculates ice thickness at random points and then interpolates predicted ice thickness at those points and the margins where it is set to 0 (Frey et al., 
2014), while such calculation is based on branchlines with GlabTop. Another difference is the DEM resolution $(50 \mathrm{~m} v \mathrm{~s} 25 \mathrm{~m}$ ) but a second run of GlabTop with the same $50 \mathrm{~m}$ resolution DEM as the one used for GlabTop2 did not explain differences in the results. Additionally, the study from Magnin et al. (2020), which also used GlabTop but with three different DEMs and other sets of branchlines, resulted in variable morphometrics from one DEM to another, but also different in places from those predicted in our study. Furthermore, the latter study shows that depths and volumes of predicted GBOs tend to be underestimated, with differences up to $50 \%$. This is more than the average 30\% uncertainty found in a comparative study by Farinotti et al. (2017) concerning absolute values of estimated ice thicknesses. While GlabTop and GlabTop2 have both been extensively used, no scientific comparison of the predicted GBOs between the two approaches and the implications for the interpretation of results have been performed yet. The use of morphological indications related to glacier flow through predicted GBOs is primarily of use for relative comparison. Application of the obtained results for, for instance, modelling of GLOFs from potential future lakes in specific cases requires detailed field investigation to assess GBOs depths, volumes and extent by, for instance IPR soundings or drillings (Le Meur and Vincent 2003; Rabatel et al., 2018).

Furthermore, classification of GBOs according to their levels of confidence is based on more or less subjective determination of criteria fulfilment, such as the slope angle threshold at which a GBO is susceptible to exist or not, or the obviousness of a bedrock threshold. A similar research conducted by another research team could lead to somewhat different quantitative appreciation but our results remain qualitatively consistent. Indeed, implication for the interpretation of results can be minimized by using the confidence level classes instead of the absolute values related to individual criteria or their simple sum. This classification allows to point out GBOs that are obvious and to define the variability in uncertainty which reflects the transitional character in nature of simply flat to markedly overdeepened bed parts.

The constant shear-stress approach used by both GlabTop models becomes especially problematic at firn divides where surface slope and, hence, basal shear stress approaches zero (Paul and Linsbauer, 2012; Guardamino et al. 2019). Estimating glacier-bed topography at firn dived still remains a problem to be solved using the Ice Thickness Models Intercomparison eXperiment (ITMIX) (Farinotti et al., 2017). In this respect, the 15 GBOs detected in the Vanoise massif on top of ice-cap like glaciers should be interpreted with caution and other modelling approaches could be used for such terrain.

Another limitation of our approach is related to debris-covered glaciers because the basic GlabTop assumption of near-equilibrium glacier conditions may be especially unrealistic for them. Such glaciers are becoming more and more extensive in the French Alps, notably in areas exposed to frequent rockfalls or rock avalanches. 30 GBOs are in this situation in the Mont Blanc massif, 7 in the Vanoise massif, 18 in the Écrins massifs, 1 in the Grandes Rousses Massif and 2 in the Ubaye massif (according to the classification by Gardent et al., 2014). In addition, the Ouille Mouta debris-covered glacier recently uncovered a rather large lake where only an insignificant GBO was predicted. Large amounts of debris supplied to glaciers and draining systems could also result in GBOs filling with sediments, hindering the formation of lakes or rapidly terminating their existence. This was the case at the snout of the Mer de Glace where a small lake formed in the 1990s and was soon filled by sediments (Deline et al., 2012; Magnin et al., 2020). In addition, lake formation in highly permeably non-consolidated material may only be temporary. Modelling sediment transport remains a challenge but could help to refine the assessment concerning the plausibility of future lake formation. Zemp et al. (2005) have developed a method that converts the sediment balance of a glacier into an erosionsedimentation index to identify glacier beds consisting of bedrock, sediments, or a mixture of both. This GIS method is automated and could help with estimating sediment input into ice-free GBOs and the potential lifetime of lakes (Linsbauer et al., 2016).

Finally, not all potential GBOs are predicted because of the input data (DEM at 25 and 50m) which can smooth the topography and the GlabTop model which does not consider glacier width reduction or crevasses (see section 4.5). Therefore, GlabTop and GlabTop2 have the main advantage to automatically detect GBOs and to provide basic morphological characteristics at least reliable to compare predicted GBOs to each other, but a visual analysis remains highly relevant for completing potential GBOs detection, even though it does not guarantee an exhaustive estimation of potential GBOs. For example, the study from Le Meur et Vincent (2003) shows a GBO on the upper part of the Saint Sorlin glacier based on interpolation of variable field measurements, upstream of the one which is predicted in this study, but it is not revealed by strikingly obvious morphological criteria.

\subsection{GBOs characteristics in the French Alps and implication for hazard assessments}

GBOs are on average two times larger in the Mont Blanc massif than in the Écrins massif and the Vanoise massif (tab. 3) and have the greater ratio of surface area to glacier extent. This may be put in relation with glacier sizes. In the Mont Blanc massif, glaciers $>2.5 \mathrm{~km}^{2}$ represent $86 \%$ of the massif's glaciated surface area, on the contrary, $75 \%$ of the glaciated surface area of the Vanoise and $72 \%$ of the Écrins are covered by glacier $<2.5 \mathrm{~km}^{2}$ (Gardent, 2014).

While predicted GBOs remain rather small compared to other high alpine areas in the world such as the Himalaya where they frequently exceed $10^{6} \mathrm{~m}^{3}$ (Linsbauer et al., 2016), their relevance in terms of hazards sources is high because downstream slopes are generally steep and adjacent valley floors often densely occupied in the French Alps. Settlements are quite often right below glacier areas, and mountain flanks are equipped with numerous infrastructures to host a variety of leisure and tourism activities. Mountain communities may thus be affected by possible dangerous high-magnitude and cascading processes associated with recently formed or potential future lakes that can develop in GBOs. Rock/ice avalanches can impact such lakes or morainic dams can suddenly breach (Allen et al., 2016a, 2016b; Ashraf et al., 2012; Clague and Evans, 2000; Emmer, 2017; Hubbard et al., 2005; Schaub et al., 2016; Schneider et al., 2014; Somos-Valenzuela et al., 2016; Worni et al., 2012). A recent example of high-magnitude chain-reaction hazards in the European Alps was associated to the Piz Cengalo rock avalanche in 2017 (3Mm³ $\mathrm{Mm}^{3}$ southern Swiss Alps), which provoked a debris flow that killed 8 people on its way and damaged about 100 infrastructures in the village of Bondo. This hazardous 
process chain did not involve any lake but was certainly favoured by the water retained in glacial sediments (Walter et al., 2020), and thus highlights how damaging such hazards could be, notably if the mass movement hits an open water body. Possible hazard issues also have to be analysed in the light of recent studies demonstrating an accentuated glacial retreat in response to summer heat waves (Rabatel et al., 2013), which also provoke permafrost degradation and enhanced rockfall activity (Ravanel and Deline, 2011; Ravanel et al., 2010; 2017; Walter et al., 2020). Therefore, glacial lakes located at the foot of high mountain rock walls subject to debuttressing and/ or permafrost degradation can become evident "hot spots". In this respect, the Mont Blanc massif appears as the most exposed one with $50 \%$ of the most plausible GBOs, the most voluminous ones (under the Talèfre, Tré la Tête glacier and Argentière glaciers). Given that the Chamonix valley is densely populated with 8759 inhabitants (INSEE, 2016), that tourism frequentation is high $(12,304,700$ overnight stays in 2016 in the Pays du Mont Blanc; Savoie Mont Blanc Tourisme, 2017) and that mountain flanks are roamed by mountaineers, hikers and contemplative tourists $(1,619,426$ tickets for the Montenvers train and the Aiguille du Midi cable car; Savoie Mont Blanc Tourisme, 2017), risks associated to sudden lake draining are exacerbated. Magnin et al. (2020) have already pointed out potential future lakes located right below high-elevated permafrost rockwalls in the Mont Blanc massif (the Pélerins or Miage glacier for example) but also suggested possible lakes that could become future opportunities for water supply (e.g., Tour glacier). Hazard potentials would have to be carefully assessed (GAPHAZ, 2017) in such cases. In addition, these results also raise questions in terms of attractiveness for tourism related to the perceptions of glacial and periglacial landscapes (Salim et al., 2019).

In the Vanoise massif, despite many predicted GBOs have a rather

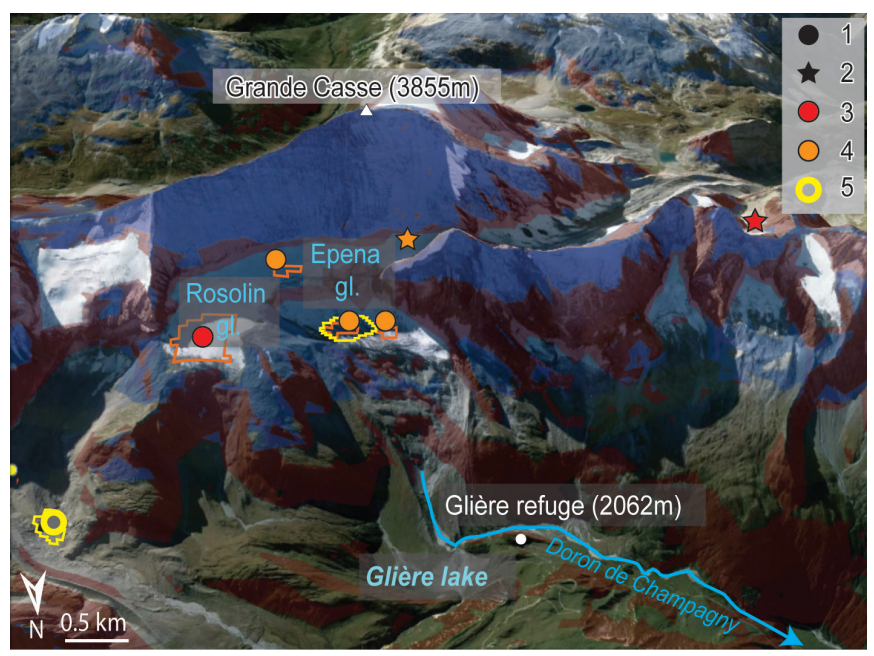

Fig. 10 - Example of possible hot spots in the Vanoise massif: The Epena and the Rosolin Glacier.

Red areas: slope $>30^{\circ}$; blue areas: permafrost favourability index $>0.5$ (Marcer et al., 2017) for the slopes $<35^{\circ}$ and permafrost favourability index $>0.5$ (Boeckli et al. 2012) for the slopes $>35^{\circ}$; Google Earth image, the altitudes are expressed in meters a.s.l. 1. GBO predicted with GlabTop; 2. GBO visually detected; 3 . High confidence; 4. Medium confidence; 5 . Absence of water body.

Fig. 10 - Exemple de hot spot possible dans le massif de la Vanoise : le glacier de l'Epena et le glacier de Rosolin.

Zones rouges : pente $>30^{\circ}$; zones bleues : indice de permafrost $>0.5$ (Marcer et al., 2017) pour les pentes $<35^{\circ}$, et indice de permafrost $>0.5$ (Boeckli et al. 2012) pour les pentes $>35^{\circ}$; image de Google Earth, les altitudes sont exprimées en mètres NGF. 1 . Surcreusement prédit par GlabTop; 2. Surcreusement détecté visuellement; 3. Confiance élevée; 4 . Confiance moyenne; 5 . Absence de lac ou de plan d'eau. low level of confidence, they might be considered as there are also many touristic infrastructures, like mountain huts or ski resorts. When considering levels of confidence, potential volumes, the presence of steep slopes and permafrost upstream, and possible vulnerabilities, the Evettes glacier, the Rosolin glacier and the Epéna glacier (fig. 10) could become hot spots as they are located right below the $700 \mathrm{~m}$-high north face of the Grande Casse (3,855m a.s.l.), which is still affected by permafrost according to the map from Boeckli et al. (2012) and feed the Doron de Champagny, that reach the touristic village of Champagny-en-Vanoise about 10km below.

Historically, Champagny-en-Vanoise has already known major GLOF events, notably in 1818 when the Glière lake became obstructed by the l'Epéna glacier tongue and suddenly discharged $3.7 \mathrm{Mm}^{3}$ in the Doron de Champagny and caused severe damages (Mougin, 2001). More recently, the lake that formed at the snout of the Patinoire glacier (fig. 7K) already outburst in 1964 because of the impact of an ice fall from the Vallonet glacier, causing an impact wave which triggered breaching of its morainic dam (fig. 11A-C). The village of Pralognanla-Vanoise was partly flooded and bridges and cars were swept up. At present, the Vallonet glacier has vanished but this lake remains a possible hot spot as it is surrounded by steep slopes (fig. 11B).

In the Écrins massif, such hot spots would be at the Fond glacier, the Sellettes glacier, the Condamines glacier, the Vallon des Étages glacier and the Blanc glacier. There, the predicted GBOs are located directly upstream from mountain huts like the Lavey refuge (under the Fond and Sellettes glaciers) (fig.12) and the Gioberney ChaletHotel (downstream from the Condamines glacier) and right below steep slopes.

It is nevertheless necessary to keep in mind that those potential lakes will form at different times. The 19 water bodies or lakes identified in recently deglaciated areas (see section 4.3), may be considered as "in formation" (e.g. Grand Méan glacier) or fully formed (e.g., Rousses glaciers) and other lakes predicted with GlabTop could form imminently (e.g., Talèfre glacier; Sellettes glacier) considering their low altitude and the current high glacier retreat rate. However, the lakes predicted in GBOs at high altitudes such as the ones possible underneath ice-cap type glaciers (e.g., under the Pelve, Arpon and Arcelin glaciers) or in the upstream parts of glaciers (e.g., Géant glacier; top of the Blanc glacier) could form later in the century.

\section{Conclusions and perspectives}

This study aimed to identify GBOs as possible locations for future lakes, by modelling glacier bed topography with GlabTop and GlabTop2 in the French Alps. The predicted GBOs were classified according to their level of confidence which was established based on a morphological analysis accounting for slope angle at and downstream of the predicted GBOs, the presence/absence of bedrock threshold and the presence/absence of a crevasse field downstream. The main outcomes are the following:

The predicted GBOs quite reliably indicate flat to markedly overdeepened parts of glacier beds, the latter especially - but not exclusively - where morphological indications are strong. Artefacts and failures must be expected at wedge-type ice margins of rapidly retreating to even decaying small glaciers and at heavily debris covered glacier tongues where sediment input is high. However, no significant water body was found were no GBO was predicted. 

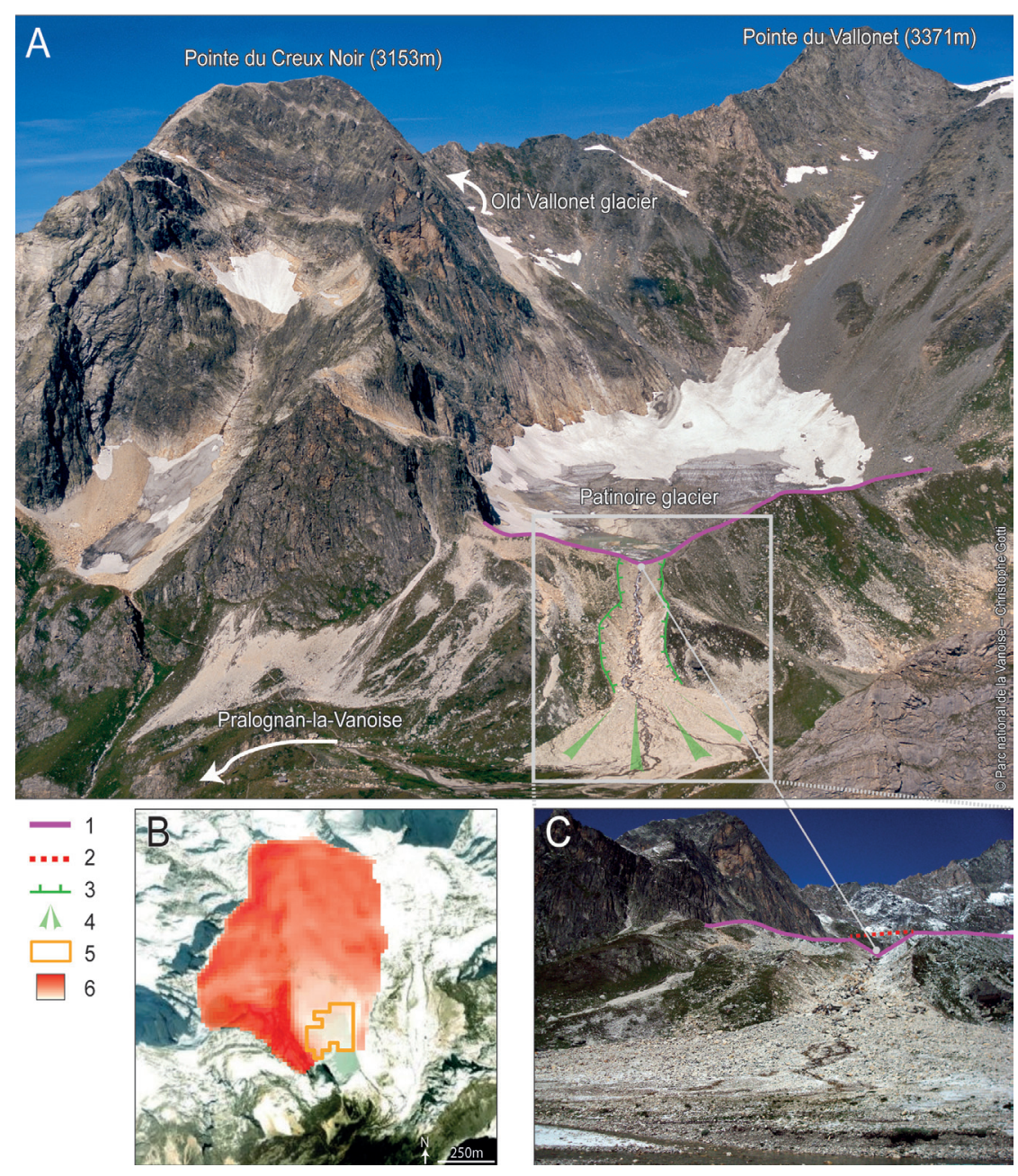

Fig. 11 - Glacial Lake Outburst Flood at the Patinoire lake.

A: Photography of the Patinoire lake watershade taken on September 5, 1997 ( ${ }^{\circledR}$ Parc national de la Vanoise - Christophe Gotti). On the picture, the marks of the GLOF of 1964 are visible in the landscape with a deep breach in the morainic dam; B: Slopes in degrees in the Patinoire lake watershade calculated with a $25 \mathrm{~m}$ DEM. (Source: Esri, Maxar, GeoEye, Earthstar Geographics, CNES/Airbus DS, USDA,USGS,AeroGRID, IGN, and the GIS User Community); C: Focus on the deep breach in the morainic dam (photography taken in 2010, ${ }^{\oplus}$ Marie Gardent). 1. Morainic dam; 2. Morainic dam old level 3. Deep breach; 4. Fluvioglacial fan; 5. GBO predicted by GlabTop2; 6 . Slope in degrees (higher value in dark red: $81.23^{\circ}$; lower value in white: $0^{\circ}$ ).

Fig. 11 - Vidange brutale du lac glaciaire de la Patinoire.

A : Photographie du lac de la Patinoire et de son basin versant prise le 5 septembre 1997 ('Parc national de la Vanoise - Christophe Gotti). Sur cette photo, les marques de la vidange brutale du lac qui a eu lieu en 1964 sont très visibles dans le paysage avec une incision profonde $d u$ barrage morainique : $B$ : Pentes en degrés du basin versant du lac de la Patinoire calculées à partir d'un MNT 25 m (Source: Esri, Maxar, GeoEye, Earthstar Geographics, CNES/Airbus DS, USDA,USGS, AeroGRID, IGN, et la communauté GIS User); C: Zoom sur l'incision profonde du barrage morainique (Photographie prise en 2010, ${ }^{\circledR}$ Marie Gardent). 1. Barrage morainique; 2. Ancien niveau du barrage morainique ; 3 . Incision profonde; 4 . Cône de dejection ; 5. Surcreusement prédit par GlabTop2; 6 Pente en degrés (Valeur haute en rouge foncé : $81,23^{\circ}$; valeur basse en blanc: $0^{\circ}$ ).

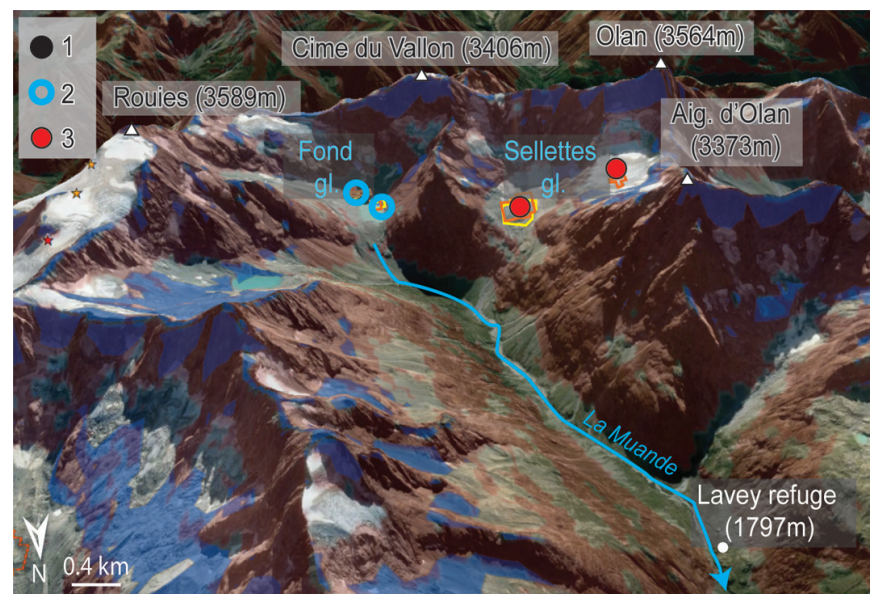

Fig. 12 - Example of possible hot spots in the Écrins massif: The Fond and the Sellettes Glacier.

Red areas: slope $>30^{\circ}$; blue areas: permafrost favourability index $>0.5$ (Marcer et al., 2017) for the slopes $<35^{\circ}$ and permafrost favourability index $>0.5$ (Boeckli et al. 2012) for the slopes $>35$; Google Earth image, the altitudes are expressed in meters a.s.l. 1. GBO predicted with GlabTop; 2 . Observed water body in recently deglaciated forefields; 3 . High confidence.

Fig. 12 - Exemple de hot spot possible dans le massif des Écrins : le glacier du Fond et le glacier des Sellettes.

Zones rouges: pente $>30^{\circ}$; zones bleues : indice de permafrost $>0.5$ (Marcer et al, 2017) pour les pentes $<35^{\circ}$, et indice de permafrost $>0.5$ (Boeckli et al. 2012) pour les pentes $>35^{\circ}$; image de Google Earth, les altitudes sont exprimées en mètres NGF. 1. Surcreusement prédit par GlabTop; 2. Lacs déjà formés dans les sur les fronts récemment désenglacés; 3 . Confiance élevée.
139 GBOs are predicted (after sorting out GlabTop and GlabTop2 output to avoid duplicated GBOs) and represent a total surface area of $9.48 \mathrm{~km}^{2}$ (3.5\% of the glacier surface area), about which $50 \%$ are in the Mont Blanc massif (40 GBOs), $30 \%$ in the Vanoise massif ( 60 GBOs) and 16\% in the Écrins massif (30 GBOs). They also represent a total volume of $217.4 \mathrm{Mm}^{3}, 67 \%$ of which is in the Mont Blanc massif, 19\% in the Vanoise massif and 9\% in the Écrins massif.

Their altitudinal distribution is directly related to the one of the related glaciers with the least elevated GBOs predicted in the Mont Blanc massif were glaciers reach the lowest elevation. However, the Écrins massif gathers half of its predicted GBOs between 2,200 and $2,500 \mathrm{~m}$ a.s.l., while this lower half is more stretched for the other massifs $(2,500-3,000 \mathrm{~m}$ a.s.l. for the Vanoise and 1,750-2,750m a.s.l. for the Mont Blanc massif). Only one single GBO is predicted $>3,500 \mathrm{~m}$ a.s.l.

Among the 139 predicted GBOs, 59 have a medium, high and very high confidence $(\geq 3 / 5)$, which means that they are likely to exist, and $50 \%$ of them are in the Mont Blanc massif. However, $73 \%$ of GBOs with a low and very low confidence $(\leq 1 / 5)$ are in the Vanoise massif which hosts many ice-cap like glaciers with firn divides which are not easily treated with the here-applied approaches. Larger and deeper GBOs all have a medium to high level of confidence.

The larger, deeper and most voluminous GBOs are predicted in the Mont Blanc massif, the deepest one being at the Argentière glacier $(146 \mathrm{~m})$ and the most voluminous one at the Talèfre glacier $\left(24.8 \mathrm{Mm}^{3}\right)$, both characterised by high levels of confidence. 
17 predicted GBOs $\left(>0.01 \mathrm{~km}^{2}\right)$ at recently deglaciated forefields have already yielded a water body. The confidence levels of the predictions were generally high for these cases. In 15 cases of GBO predictions at generally low confidence levels, dry conditions are combined with the absence of marked bedrock thresholds, relatively steep slopes $>10-15^{\circ}$, or dynamic sediment infilling. Additionally, two lakes already $>0,01 \mathrm{~km}^{2}$ or possibly growing to that size in the future have started to form where GBOs $<0,01 \mathrm{~km}$ were predicted.

In addition to the GlabTop results, 58 GBOs have been visually detected by analysing glacier morphologies, among which 30 are in the Vanoise massif, 15 in the Mont Blanc massif, 12 in the Écrins massif and 1 in the Grandes Rousses massif. four of them are $>3,500 \mathrm{~m}$ a.s.l.

Our study provides key-information about rapidly emerging high-mountain landscapes as a consequence of glacier retreat to even vanishing. It represents an essential first step for potential future research, which will constitute a basis of reflection for decision-makers in long-term planning. Although the predicted depths and volumes of GBOs remain uncertain, their location and level of confidence are relevant to anticipate potential future lake formation and to serve as a guide to possible hot spots in terms of GLOF hazards but also of opportunities related to water resources, hydropower production and tourism in the French Alps. The resulting inventory of potential future lakes especially indicates where more detailed investigation should be conducted in areas of interest. This could involve modelling of glacier retreat to assess the time range under which potential lakes could form, geophysical soundings to assess GBOs morphometrics, or numerical model calculations of potentially involved process chains following rock/ ice avalanches and related displacement/flood waves or debris flows to assess possible impacts, hazards and risks to humans and their infrastructure.

\section{Acknowledgements}

The authors acknowledge Horst Machguth (Department of Geosciences, University of Fribourg, Switzerland) for modelling glacier ice thickness distribution with GlabTop2. The study received no financial support for this research.

\section{References}

Allen S.K., Linsbauer A., Randhawa S.S., Huggel C., Rana P., Kumari A. (2016a) - Glacial lake outburst flood risk in Himachal Pradesh, India: an integrative and anticipatory approach considering current and future threats. Natural Hazards, 84 (3), 1741-1763.

DOI : $10.1007 / \mathrm{s} 11069-016-2511-\mathrm{x}$

Allen S.K., Rastner P., Arora M., Huggel C. Stoffel M. (2016b) Lake outburst and debris flow disaster at Kedarnath, June 2013: hydrometeorological triggering and topographic predisposition. Landslides, 13 (6), 1479-1491.

DOI : $10.1007 / \mathrm{s} 10346-015-0584-3$

Ashraf A., Naz R. Roohi R. (2012) - Glacial lake outburst flood hazards in Hindukush, Karakoram and Himalayan Ranges of Pakistan: implications and risk analysis. Geomatics, Natural Hazards and Risk, 3 (2), 113-132.

\section{DOI : $10.1080 / 19475705.2011 .615344$}

Boeckli L., Brenning A., Gruber S., Noetzli J. (2012) - Permafrost Distribution in the European Alps: Calculation and Evaluation of an Index Map and Summary Statistics. The Cryosphere, 6 (4), 807-820.

DOI : $10.5194 /$ tc- $6-807-2012$

Böhm R., Jones P.D., Hiebl J., Frank D., Brunetti M., Maugeri M. (2010) - The early instrumental warm-bias: a solution for long central European temperature series 1760-2007. Climatic Change, 101 (1-2), 41-67.

DOI : $10.1007 / \mathrm{s} 10584-009-9649-4$

Byers A.C., Rounce D. R., Shugar D.H., Lala J.M., Byers E.A., Regmi D. (2018) - A rockfall-induced glacial lake outburst flood, Upper Barun Valley, Nepal. Landslides 16, 533-549.

DOI : $10.1007 /$ s10346-018-1079-9

Carey M. (2005) - Living and dying with glaciers: people's historical vulnerability to avalanches and outburst floods in Peru. Global and Planetary Change, 47 (2), 122-134.

DOI : 10.1016/j.gloplacha.2004.10.007

Carey M., Huggel C., Bury J., Portocarrero C. Haeberli W. (2012) An integrated socio-environmental framework for glacier hazard management and climate change adaptation: lessons from Lake 513, Cordillera Blanca, Peru. Climatic Change, 112 (3), 733-767. DOI : 10.1007/s10584-011-0249-8

Clague J.J., Evans S.G. (2000) - A review of catastrophic drainage of moraine-dammed lakes in British Columbia. Quaternary Science Reviews, 19 (17), 1763-1783.

DOI : $10.1016 /$ S0277-3791(00)00090-1

Colonia D., Torres J., Haeberli W., Schauwecker S., Braendle E., Giraldez C., Cochachin A. (2017) - Compiling an Inventory of Glacier-Bed Overdeepenings and Potential New Lakes in DeGlaciating Areas of the Peruvian Andes: Approach, First Results, and Perspectives for Adaptation to Climate Change. Water, 9 (5), 336.

DOI : $10.3390 /$ w9050336

Deline P., Gardent M., Magnin F., Ravanel L. (2012) - The morphodynamics of the Mont Blanc massif in a changing cryosphere: A comprehensive review. Geografiska Annaler (Series A, Physical Geography), 94 (2), 265-283.

DOI : $10.1111 /$ j.1468-0459.2012.00467.x

Drenkhan F., Guardamino L., Huggel C., Frey H. (2018) - Current and future glacier and lake assessment in the deglaciating Vilcanota-Urubamba basin, Peruvian Andes. Global and Planetary Change, 169, 105-118.

DOI : 10.1016/j.gloplacha.2018.07.005

Einhorn B., Eckert N., Chaix C., Ravanel L., Deline P., Gardent M., Boudières V., Richard D., Vengeon J.-M., Giraud G., Schoeneich P. (2015) - Changements climatiques et risques naturels dans les Alpes. Impacts observés et potentiels sur les systèmes physiques et socio-économiques. Revue de Géographie Alpine, 103 (2). DOI : $10.4000 /$ rga.2829

Emmer A. (2017) - Glacier Retreat and Glacial Lake Outburst Floods (GLOFs), Oxford Research Encyclopedia of Natural Hazard Science.

DOI : 10.1093/acrefore/9780199389407.013.275

Farinotti D., Brinkerhoff D.J., Clarke G.K.C., Fürst J.J., Frey H., 
Gantayat P., Gillet-Chaulet F., Girard C., Huss M., Leclercq P.W., Linsbauer A., Machguth H., Martin C., Maussion F., Morlighem M., Mosbeux C., Pandit A., Portmann A., Rabatel A., Ramsankaran R., Reerink T.J., Sanchez O., Stentoft P.A., Singh Kumari S., Pvan Pelt W.J.J., Anderson B., Benham T., Binder D., Dowdeswell J.A., Fischer A. Helfricht K., Kutuzov S., Lavrentiev I., McNabb R., Gudmundsson G.H., Li H., Andreassen L.M. (2017) - How accurate are estimates of glacier ice thickness? Results from ITMIX, the Ice Thickness Models Intercomparison eXperiment. The Cryosphere, 11 (2), 949-970. DOI : $10.5194 / \mathrm{tc}-11-949-2017$

Farinotti D., Huss M., Bauder A., Funk,M. (2009) - An estimate of the glacier ice volume in the Swiss Alps. Global and Planetary Change, 68 (3), 225-231.

DOI : 10.1016/j.gloplacha.2009.05.004

Frey H., Haeberli W., Linsbauer A., Huggel C., Paul F. (2010) - A multi-level strategy for anticipating future glacier lake formation and associated hazard potentials. Natural Hazards and Earth System Sciences, 10 (2), 339-352.

DOI : $10.5194 /$ nhess-10-339-2010

Frey H., Machguth H., Huss M., Huggel C., Bajracharya S., Bolch T., Kulkarni A., Linsbauer A., Salzmann N., Stoffel M. (2014) Estimating the volume of glaciers in the Himalayan-Karakoram region using different methods. The Cryosphere, 8 (6). https : //doc.rero.ch/record/234306

GAPHAZ (2017) - Assessment of Glacier and Permafrost Hazards in Mountain Regions - Technical Guidance Document, International Association of Cryospheric Sciences (IASC) and the International Permafrost Association (IPA), Zurich, Switzerland / Lima, Peru. 72 p.

Gardent M. (2014) - Inventaire et retrait des glaciers dans les alpes françaises depuis la fin du Petit Age Glaciaire. Thèse de doctorat, Université Savoie Mont-Blanc, 455 p.

Gardent M., Rabatel A., Dedieu J.-P., Deline P. (2014) Multitemporal glacier inventory of the French Alps from the late 1960 s to the late 2000s. Global and Planetary Change, 120, 24-37. DOI : 10.1016/j.gloplacha.2014.05.004

Guardamino L., Haeberli W., Muñoz R., Drenkhan F., Tacsi A. Cochaching A. (2019) - Proyección de lagunas Futuras en las Cordilleras Glaciares del Perú. Ministra de Agricultura y Riego, Autoridad Nacional del Agua, Dirección de Calidad y Evaluación de Calidad de Recursos Hídricos, Área de Evaluación de Glaciares y Lagunas.

http : //repositorio.ana.gob.pe/handle/ANA/3597

Haeberli W. (2017) - Integrative modelling and managing new landscapes and environments in de-glaciating mountain ranges: An emerging trans-disciplinary research field. Forestry Research and Engineering: International Journal, 1 (1).

DOI : $10.15406 /$ freij.2017.01.00005

Haeberli W., Buetler M., Huggel C., Lehmann Friedli T., Schaub Y., Schleiss A. (2016) - New lakes in deglaciating high-mountain regions - opportunities and risks. Climate Change, 2 (139), 201-214.

http : //dx.doi.org/10.1007/s10584-016-1771-5

Haeberli W., Kääb A., Vonder Mühll D., Teysseire P. (2001) - Prevention of outburst floods from periglacial lakes at Grubengletscher, Valais, Swiss Alps. Journal of Glaciology, 47
(156), 111-122.

\section{DOI : $10.3189 / 172756501781832575$}

Haeberli W., Schaub Y. Huggel C. (2017) - Increasing risks related to landslides from degrading permafrost into new lakes in deglaciating mountain ranges. Geomorphology 293, 405-417. DOI : 10.1016/j.geomorph.2016.02.009

Hock R., Rasul G., Adler C., Cáceres B., Gruber S., Hirabayashi Y., Jackson M., Kääb A., Kang S., Kutuzov S., Milner A., Molau U., Morin S., Orlove B., Steltzer H. (2019) - High Mountain Areas. In Pörtner H.-O., Roberts D.C., Masson-Delmotte V., Zhai P., Tignor M., Poloczanska E., Mintenbeck K., Alegría A., Nicolai M., Okem A., Petzold J., Rama B., Weyer N.M. (Eds.): IPCC Special Report on the Ocean and Cryosphere in a Changing Climate. In chapter 2.

https : //www.ipcc.ch/srocc/chapter/chapter-2/

Hubbard B., Heald A., Reynolds J. M., Quincey D., Richardson S. D., Luyo M. Z., Portilla N. S. Hambrey M. J. (2005) - Impact of a rock avalanche on a moraine-dammed proglacial lake: Laguna Safuna Alta, Cordillera Blanca, Peru, Earth Surface Processes and Landforms, 30 (10), 1251-1264.

DOI : $10.1002 /$ esp. 1198

Huss M. (2012) - Extrapolating glacier mass balance to the mountain range scale: The European Alps 1900-2100. The Cryosphere Discuss. 6, 1117-1156. DOI : $10.5194 /$ tcd-6-1117-2012

INSEE (2019) - Comparateur de territoire - Commune de Chamonix-Mont-Blanc (74056). Insee.

https : //www.insee.fr/fr/statistiques/1405599?.geo=COM-74056

Kapitsa V., Shahgedanova M., Machguth H., Severskiy I., Medeu A. (2017) - Assessment of evolution and risks of glacier lake outbursts in the Djungarskiy Alatau, Central Asia, using Landsat imagery and glacier bed topography modelling. Natural Hazards and Earth System Sciences, 17 (10), 1837-1856.

DOI : $10.5194 /$ nhess-17-1837-2017

Le Meur E. L. Vincent C. (2003) - A two-dimensional shallow ice-flow model of Glacier de Saint-Sorlin, France. Journal of Glaciology, 49 (167), 527-538.

DOI : 10.3189/172756503781830421

Linsbauer, A., Frey H., Haeberli W., Machguth H., Azam M. F., Allen S. (2016) - Modelling glacier-bed overdeepenings and possible future lakes for the glaciers in the Himalaya - Karakoram region. Annals of Glaciology, 57 (71), 119-130.

DOI : $10.3189 / 2016$ AoG71A627

Linsbauer A., Paul F, Hoelzle M., Frey H. Haeberli W. (2009) - The Swiss Alps without glaciers - a GIS-based modelling approach for reconstruction of glacier beds. Proceedings of Geomorphometry 2009. Zurich, Switzerland, 243-247

DOI : $10.5167 /$ uzh-27834

Linsbauer A., Paul F., Haeberli W. (2012) - Modelling glacier thickness distribution and bed topography over entire mountain ranges with GlabTop: Application of a fast and robust approach. Journal of Geophysical Research: Earth Surface, 117 (F3), 17. DOI : $10.1029 / 2011$ JF002313

Magnin F., Josnin J.-Y., Ravanel L., Pergaud J., Pohl B., Deline P. (2017) - Modelling rock wall permafrost degradation in the Mont Blanc massif from the LIA to the end of the 21st century. The Cryosphere, 11 (4), 1813-1834. 
DOI : $10.5194 / \mathrm{tc}-11-1813-2017$

Magnin F., Haeberli W., Linsbauer A., Deline P., Ravanel L. (2020) - Estimating glacier-bed overdeepenings as possible sites of future lakes in the de-glaciating Mont Blanc massif (Western European Alps), Geomorphology, 350, 106913.

DOI : 10.1016/j.geomorph.2019.106913

Marcer M., Bodin X., Brenning A., Schoeneich P., Charvet R., Gottardi F. (2017) - Permafrost Favorability Index: Spatial Modeling in the French Alps Using a Rock Glacier Inventory. Frontiers in Earth Science, 5.

DOI : $10.3389 /$ feart.2017.00105

Mougin P. (2001) - Les torrents de la Savoie, Eds. La Fontaine de Siloé, $1251 \mathrm{p}$.

Paul F., Linsbauer A. (2012) - Modeling of glacier bed topography from glacier outlines, central branch lines, and a DEM. International Journal of Geographical Information Science, 26 (7), 1173-1190. DOI : $10.1080 / 13658816.2011 .627859$

PERMOS (2019) - Permafrost in Switzerland, 2014/2015 to 2017/2018. Commission of the Swiss Academy of Sciences. [online].

DOI : $10.13093 /$ permos-rep-2019-16-19

Purdie H. (2013) - Glacier Retreat and Tourism: Insights from New Zealand. Mountain Research and Development, 33 (4), 463-472. DOI : 10.1659/MRD-JOURNAL-D-12-00073.1

Rabatel A., Letréguilly A., Dedieu J.-P., Eckert N. (2013) Changes in glacier equilibrium-line altitude in the western Alps from 1984 to 2010: Evaluation by remote sensing and modeling of the morpho-topographic and climate controls. The Cryosphere, 7 (5), 1455-1471.

DOI : $10.5194 / \mathrm{tc}-7-1455-2013$

Rabatel A., Sanchez O., Vincent C., Six D. (2018) - Estimation of Glacier Thickness From Surface Mass Balance and Ice Flow Velocities: A Case Study on Argentière Glacier, France. Frontiers in Earth Science, 6 (112). DOI : $10.3389 /$ feart.2018.00112

Ravanel L., Magnin F., Deline P. (2017) - Impacts of the 2003 and 2015 summer heatwaves on permafrost-affected rock-walls in the Mont Blanc massif. Science of The Total Environment, 609, 132-143.

DOI : 10.1016/j.scitotenv.2017.07.055

Ravanel L., Allignol F., Deline P., Gruber S., Ravello M. (2010) Rock falls in the Mont Blanc Massif in 2007 and 2008. Landslides, 7 (4), 493-501.

DOI : $10.1007 / \mathrm{s} 10346-010-0206-\mathrm{Z}$

Ravanel L., Deline P. (2011) - Climate influence on rockfalls in high-Alpine steep rockwalls: The north side of the Aiguilles de Chamonix (Mont Blanc massif) since the end of the 'Little Ice Age'. The Holocene, 21 (2), 357-365.

DOI : $10.1177 / 0959683610374887$

Salim E., Mourey J., Ravanel L., Picco P., Gauchon C. (2019) Mountain guides facing the effects of climate change. What perceptions and adaptation strategies at the foot of Mont Blanc? Journal of Alpine Research | Revue de Géographie Alpine, 107-4, Article 107-4.

DOI : $10.4000 /$ rga. 5865

Savoie Mont Blanc Tourisme (2017) - Chiffres 2017 Savoie Mont
Blanc Tourisme (p. 8) [Zoom territoire]. Pays du Mont Blanc (unpublished)

https : //www.ccpmb.fr/uploads/2017/07/Chiffres-2017 savoiemont-blanc-tourisme.pdf

Schaub Y., Huggel C. Cochachin A. (2016) - Ice-avalanche scenario elaboration and uncertainty propagation in numerical simulation of rock-/ice-avalanche-induced impact waves at Mount Hualcán and Lake 513, Peru, Landslides, 13 (6), 1445-1459.

DOI : $10.1007 / \mathrm{s} 10346-015-0658-2$

Schneider D., Huggel C., Cochachin A., Guillén S. García J. (2014) - Mapping hazards from glacier lake outburst floods based on modelling of process cascades at Lake 513, Carhuaz, Peru. Advanced Geosciences, 35, 145-155.

DOI : 10.5194/adgeo-35-145-2014

Somos-Valenzuela M. A., Chisolm R. E., Rivas D. S., Portocarrero C., McKinney D. C. (2016) - Modelling a glacial lake outburst flood process chain: the case of Lake Palcacocha and Huaraz, Peru. Hydrology and Earth System Sciences, 20 (6), 2519-2543. DOI : $10.5194 /$ hess-20-2519-2016

Vincent C., Moreau L. (2016) - Sliding velocity fluctuations and subglacial hydrology over the last two decades on Argentière glacier, Mont Blanc area. Journal of Glaciology, 62, 805-815. DOI : $10.1017 /$ jog.2016.35

Vincent C., Peyaud V., Laarman O., Six D., Gilbert A., GilletChaulet F., Berthier É., Morin S., Verfaillie D., Rabatel A., Jourdain B., Bolibar J. (2019) - Déclin des deux plus grands glaciers des Alpes françaises au cours du XXIe siècle : Argentière et Mer de Glace. La Météorologie, 106, 49.

DOI : 10.4267/2042/70369

Walter F., Amann F., Kos A., Kenner R., Phillips M., de Preux A., Huss M., Tognacca C., Clinton J., Diehl T. Bonanomi Y. (2020) - Direct observations of a three million cubic meter rock-slope collapse with almost immediate initiation of ensuing debris flows. Geomorphology, 351, 106933. DOI : 10.1016/j.geomorph.2019.106933

Worni R., Stoffel M., Huggel C., Volz C., Casteller A. Luckman B. (2012) - Analysis and dynamic modeling of a moraine failure and glacier lake outburst flood at Ventisquero Negro, Patagonian Andes (Argentina). Journal of Hydrology, 444-445, 134-145. DOI : 10.1016/j.jhydrol.2012.04.013

Zekollari H., Huss M., Farinotti D. (2019) - Modelling the future evolution of glaciers in the European Alps under the EUROCORDEX RCM ensemble. The Cryosphere, 13 (4), 1125-1146. DOI : $10.5194 / \mathrm{tc}-13-1125-2019$

Zemp M., Haeberli W., Hoelzle M., Paul F. (2006) - Alpine glaciers to disappear within decades? Geophysical Research Letters, 33 (13).

DOI : $10.1029 / 2006$ GL026319

Zemp M., Kääb A., Hoelzle M., Haeberli W. (2005) - GIS-based modelling of glacial sediment balance. 18 .

DOI : $10.5167 /$ uzh- 40580

Zemp M., Frey H., Gärtner-Roer I., Nussbaumer S. U., Hoelzle M., Paul F., Haeberli W., Denzinger F., Ahlstrøm A.P., Anderson B., Bajracharya S., Baroni C., Braun L.N., Cáceres B.E., Casassa G., Cobos G., Dávila L.R., Granados H.D., Demuth M.N., Espizua L., Fischer A., Fujita K., Gadek B., Ghazanfar A., Hagen J.O., Holmlund P., Karimi N., Li Z., Pelto M., Pitte 
P., Popovnin V.V., Portocarrero C.A., Prinz R., Sangewar C.V., Severskiy I., Sigurðsson O., Soruco A., Usubaliev R., Vincent C. (2015) - Historically unprecedented global glacier decline in the early 21 st century. Journal of Glaciology, 61 (228), 745-762. DOI : 10.3189/2015JoG15J017

\section{Version française abrégée}

Depuis la fin du Petit Age Glaciaire, les Alpes françaises (fig. 1) subissent un recul généralisé des glaciers (Gardent et al., 2014) laissant parfois place à la formation de nouveaux lacs dans les surcreusements des lits glaciaires. Ces lacs sont situés dans des environnements par nature instables (terrain à permafrost, accumulations sédimentaires non consolidées, etc.) et peuvent constituer des sources ou des amplificateurs d'aléas naturels (e.g., lave torrentielle provoquée par la vidange brutale d'un lac) atteignant parfois les fonds de vallée (Byers et al., 2018 ; Walter et al., 2020). Néanmoins, ils peuvent également être source de nouvelles opportunités économiques, grâce à leur attractivité touristique ou leur potentiel hydro-électrique. La modélisation des futurs paysages glaciaires et périglaciaires est nécessaire pour anticiper les risques éventuels et/ou les opportunités futures (Haeberli, 2016). Ce travail vise ainsi à détecter et caractériser de potentiels surcreusements sous glaciaires dans lesquels des lacs pourraient se former afin de fournir une base de données pertinente pour anticiper les risques et les opportunités à venir dans les Alpes françaises.

Pour ce faire, une modélisation de la topographie sous glaciaire a été effectuée grâce aux modèles GlabTop (Glacier-bed Topography) et GlabTop2 qui permettent de calculer l'épaisseur de glace à partir d'une relation empirique entre la contrainte moyenne de cisaillement basal et la dénivellation du glacier (Linsbauer et al., 2009, 2012 ; Paul et Linsbauer, 2012). Ces deux modèles utilisent un Modèle Numérique de Terrain (MNT) et une délinéation des glaciers comme données d'entrée. GlabTop utilise des lignes de flux glaciaires digitalisées manuellement pour les calculs d'épaisseur alors que GlabTop2 les implémente de manière automatique. L'épaisseur de glace calculée est ensuite soustraite à la topographie du MNT d'entrée afin de produire un MNT sans glaciers à partir duquel sont identifiés les surcreusements (fig. 2). Lors de l'analyse des résultats, les sorties des deux modèles ont d'abord été comparées (fig. 3-4, tab. 2), puis combinées, en supprimant les surcreusements communs, et en retenant les données relatives aux caractéristiques des surcreusements (superficies, profondeurs et volumes) prédits par GlabTop uniquement. Les résultats ont ensuite été évalués en fonctions de la présence/absence de lacs dans les secteurs désenglacés depuis 2004-2009, période à partir de laquelle l'inventaire des glaciers utilisé en entrée des modèles a été réalisé. Une analyse morphologique basée sur la méthode Frey et al. (2010) permet de classer les surcreusements sous glaciaires prédits par GlabTop (2) afin de déterminer la susceptibilité qu'un lac se forme en prenant en compte [I] l'angle de pente au niveau du surcreusement, [II] la présencelabsence d'une rupture de pente à l'aval du surcreusement, [III] la présencelabsence d'un verrou rocheux et une réduction de la largeur du glacier à l'aval du surcreusement prédit, [IV] la transition entre une zone sans crevasses et avec crevasses ou chute de séracs à l'aval du surcreusement. Une valeur de 0 à 5 est attribuée à chacun des critères (tab. 1), puis le pourcentage de la somme de tous les critères par rapport à la somme totale possible (20 si les 4 critères sont identifiables et à leur maximum) permet de classer chaque surcreusement selon un niveau de confiance allant de "très peu élevé » (0/5 pour 0 à $10 \%$ des critères remplis) à " très élevé 》 (5/5 pour 90 à $100 \%$ des critères remplis). Enfin, d'autres surcreusements potentiels ont été visuellement détectés puis classés dans les zones où les critères [I] et [II] sont $\geq 3$.

Au total, 139 surcreusements $\left(>0,01 \mathrm{~km}^{2}\right)$ ont été prédits dans les Alpes françaises, dont 40 dans le massif du Mont Blanc, 60 en Vanoise, 30 dans les Ecrins, 6 dans les Grandes Rousses, deux en Ubaye et un dans le Ruans (fig. 2, tab. 3). Ces surcreusements représentent une surface de $9,5 \mathrm{~km}^{2}$ (3,5\% de la surface des glaciers), dont $50 \%$ se trouvent dans le massif du Mont Blanc $\left(4,8 \mathrm{~km}^{2}\right), 30 \%$ en Vanoise $\left(2,7 \mathrm{~km}^{2}\right)$ et $16 \%$ dans les Ecrins $\left(1,6 \mathrm{~km}^{2}\right)$. Ils représentent un volume total de 217,4 Mm³ , dont $67 \%$ est dans le massif du Mont Blanc, $19 \%$ dans celui de la Vanoise et $9 \%$ dans les Ecrins. Les surcreusements les plus larges, les plus profonds et les plus volumineux sont situés dans le massif du Mont Blanc (fig. 5). Le plus profond se trouve sous le glacier d'Argentière $(146 \mathrm{~m}$ ) et le plus volumineux sous le glacier de Talèfre $\left(24,8 \mathrm{Mm}^{3}\right)$, et sont tous deux caractérisés par un haut niveau de confiance.

Par ailleurs, la distribution altitudinale des surcreusements est liée à celle des glaciers: les plus hauts et les plus bas en altitude sont prédits dans le massif du Mont Blanc (respectivement $1570 \mathrm{~m}$ à la Mer de Glace et $4507 \mathrm{~m}$ au glacier des Bossons). Dans l'ensemble des Alpes françaises, une large majorité des surcreusements prédits par GlabTop se situent en dessous de $3500 \mathrm{~m}$.

Parmi les 139 surcreusements, 59 ont un niveau de confiance moyennement élevé à très élevé $\geq 3 / 5$ (fig. 6). Le massif du Mont Blanc rassemble 16 des 32 surcreusements qui ont un niveau de confiance élevé à très élevé ( $\geq 4 / 5)$. En revanche, $73 \%$ des surcreusements qui ont un faible niveau de confiance $(\leq 1 / 5)$ se situent dans le massif de la Vanoise, notamment sous les calottes glaciaires, pour lesquelles ni les critères de l'analyse morphologique, ni GlabTop (2) ne sont adaptés. Sur le front des glaciers récemment désenglacés, 20 lacs se sont déjà formés ou sont en cours de formation dans 31 des surcreusements prédits (fig. 6-7), ainsi que quatre autres dans des surcreusements $<0,01 \mathrm{~km}^{2}$ selon les estimations de GlabTop (fig. 8). L'absence de lac dans les 15 autres cas s'explique le plus souvent par une absence de verrou rocheux, par une pente $>10^{\circ}-15^{\circ}$ ou par un remplissage sédimentaire (fig. 9). En plus des surcreusements potentiels détectés par les modèles GlabTop, 58 autres ont été détectés visuellement en analysant la morphologie des glaciers, dont 30 en Vanoise, 15 dans le massif du Mont Blanc, 12 dans celui des Ecrins et un dans les Grandes Rousses.

Bien que les estimations des profondeurs et des volumes des surcreusements demeurent incertaines (Magnin et al., 2020), leur localisation et leur niveau de confiance sont pertinents pour anticiper les futurs "hot spots " éventuels en termes de risques (fig. 10-12), mais également pour saisir les opportunités liées à la ressource en eau dans les Alpes françaises. Notre étude constitue une première étape essentielle à de futures recherches impliquant des modélisations de retrait glaciaire afin d'évaluer l'échelle de temps sur laquelle les lacs potentiels pourraient se former, des sondages géophysiques pour estimer les volumes des surcreusements, ou encore des modélisations de trajectoire pour évaluer les impacts potentiels des aléas générés ou amplifiés par ces lacs. 